\title{
RESEARCH
}

Open Access

\section{Impact of ambient temperature on inflammation-induced encephalopathy in endotoxemic mice-role of phosphoinositide 3-kinase gamma}

Guang-Ping Lang ${ }^{1,2}$, Bernadin Ndongson-Dongmo ${ }^{1,3}$, Trim Lajai ${ }^{1,4}$, Michael Brodhun ${ }^{5}$, Yingying Han ${ }^{6}$, Reinhard Wetzker ${ }^{7}$, Martin G. Frasch ${ }^{8}$ and Reinhard Bauer ${ }^{1 *}$ (D)

\begin{abstract}
Background: Sepsis-associated encephalopathy (SAE) is an early and frequent event of infection-induced systemic inflammatory response syndrome. Phosphoinositide 3-kinase $Y$ (PI3KY) is linked to neuroinflammation and inflammation-related microglial activity. In homeotherms, variations in ambient temperature $\left(T_{a}\right)$ outside the thermoneutral zone lead to thermoregulatory responses, mainly driven by a gradually increasing sympathetic activity, and may affect disease severity. We hypothesized that thermoregulatory response to hypothermia (reduced $\mathrm{T}_{\mathrm{a}}$ ) aggravates SAE in PI3KY-dependent manner.

Methods: Experiments were performed in wild-type, PI3KY knockout, and PI3Ky kinase-dead mice, which were kept at neutral $\left(30 \pm 0.5^{\circ} \mathrm{C}\right)$ or moderately lowered $\left(26 \pm 0.5^{\circ} \mathrm{C}\right) \mathrm{T}_{\mathrm{a}}$. Mice were exposed to lipopolysaccharide (LPS, $10 \mathrm{\mu g} / \mathrm{g}$, from Escherichia coli serotype 055:B5, single intraperitoneal injection)—evoked systemic inflammatory response (SIR) and monitored $24 \mathrm{~h}$ for thermoregulatory response and blood-brain barrier integrity. Primary microglial cells and brain tissue derived from treated mice were analyzed for inflammatory responses and related cell functions. Comparisons between groups were made with one-way or two-way analysis of variance, as appropriate. Post hoc comparisons were made with the Holm-Sidak test or $t$ tests with Bonferroni's correction for adjustments of multiple comparisons. Data not following normal distribution was tested with Kruskal-Wallis test followed by Dunn's multiple comparisons test.

Results: We show that a moderate reduction of ambient temperature triggers enhanced hypothermia of mice undergoing LPS-induced systemic inflammation by aggravated SAE. PI3KY deficiency enhances blood-brain barrier injury and upregulation of matrix metalloproteinases (MMPs) as well as an impaired microglial phagocytic activity.

\footnotetext{
* Correspondence: Reinhard.Bauer@med.uni-jena.de

The work was performed at the Institute of Molecular Cell Biology, Jena University Hospital, Friedrich Schiller University, Jena, Germany.

'Institute of Molecular Cell Biology, Jena University Hospital, Friedrich Schiller University, Hans-Knöll-Straße 2, D-07745 Jena, Germany

Full list of author information is available at the end of the article
}

(c) The Author(s). 2020 Open Access This article is licensed under a Creative Commons Attribution 4.0 International License, which permits use, sharing, adaptation, distribution and reproduction in any medium or format, as long as you give appropriate credit to the original author(s) and the source, provide a link to the Creative Commons licence, and indicate if changes were made. The images or other third party material in this article are included in the article's Creative Commons licence, unless indicated otherwise in a credit line to the material. If material is not included in the article's Creative Commons licence and your intended use is not permitted by statutory regulation or exceeds the permitted use, you will need to obtain permission directly from the copyright holder. To view a copy of this licence, visit http://creativecommons.org/licenses/by/4.0/ The Creative Commons Public Domain Dedication waiver (http://creativecommons.org/publicdomain/zero/1.0/) applies to the data made available in this article, unless otherwise stated in a credit line to the data. 


\begin{abstract}
(Continued from previous page)
Conclusions: Thermoregulatory adaptation in response to ambient temperatures below the thermoneutral range exacerbates LPS-induced blood-brain barrier injury and neuroinflammation. PI3KY serves a protective role in suppressing release of MMPs, maintaining microglial motility and reinforcing phagocytosis leading to improved brain tissue integrity. Thus, preclinical research targeting severe brain inflammation responses is seriously biased when basic physiological prerequisites of mammal species such as preferred ambient temperature are ignored.
\end{abstract}

Keywords: Neuroinflammation, Ambient temperature, Microglia, Phosphoinositide 3-kinase $\gamma$, Blood-brain barrier, Matrix metalloproteinases, Phagocytosis, Migration

\section{Background}

Sepsis-associated encephalopathy (SAE) is the most common form of encephalopathy occurring in critical care settings and refers to acute neurological dysfunction that arises in the context of extracranial sepsis. SAE is an early feature of infection in the body, occurs quite often with a prevalence of up to $30 \%$ in septicemic patients at admission, and SAE severity is associated with increased mortality of septic patients [1]. Although the symptoms of SAE are well recognized-it can take the form of delirium, coma, seizures, or late cognitive decline-its pathophysiology is incompletely understood [2].

Several mechanisms of SAE have been proposed. The hallmarks are thought to comprise diffuse neuroinflammation likely driven by an initial blood-brain barrier (BBB) leakage leading to microglial activation and altered neurotransmission [3]. Activation of cerebral microvascular endothelial cells as the primary constituent of the BBB is regarded as an early event, induced by interaction with a pathogen product such as lipopolysaccharide (LPS) via pattern recognition receptors and proinflammatory factors. The latter include activated complement components and cytokines and lead to an increased endothelial production of reactive oxygen and nitrogen species, accelerated transendothelial cytokine trafficking, and enhanced endothelial permeability [4]. Microglial proinflammatory response further reinforces $\mathrm{BBB}$ breakdown and modifies it via PI3K $\gamma$-depended cAMP control [5].

Microglia are considered to be the prototypic tissueresident macrophage-like innate immune cells of the central nervous system (CNS) that are endowed with memory-like functions to allow context-dependent responses [6-8]. Microglia represent the resident macrophage-like cell population that controls the patterning and wiring of the brain in early development and contributes to homeostasis throughout life [9-12]. Furthermore, microglia implement innate immunity in the CNS as a first line of defense against invading pathogens by continuous micro-environmental surveillance [11, 13-17]. Alterations in brain homeostasis and by most pathologic events induce activation of microglia [18]. During the activation process, microglial cells display specific adaptive functions, including migration towards injury, phagocytosis, antigen presentation, and synapse remodeling [19-21].

Thermoregulation is a fundamental homeostatic function of all mammals; it includes afferent thermal sensing, central regulation, and an efferent response resulting in a tightly controlled body temperature within a narrow species-specific range [22]. Variations of core body temperature $\left(\mathrm{T}_{\mathrm{C}}\right)$ outside this range trigger autonomic thermoregulatory responses, mainly via a gradually increased sympathetic activity to minimize radiant heat loss by skin vasoconstriction and maximize heat production by brown adipose tissue thermogenesis [23]. Clinical data clearly indicate that poor outcome of sepsis is associated with spontaneous $T_{C}$ lowering (hypothermia indicating energy depletion) [24-26]. Subgroups of patients with increased risk to develop sepsis such as trauma or burns fail thermal regulation leading frequently to accidental hypothermia $[27,28]$. However, in pathogenesis of SAE, the role of challenged thermoregulation upon exposure to a reduced ambient temperature $\left(\mathrm{T}_{\mathrm{a}}\right)$ and the resulting accidental hypothermia have not been studied. Moreover, in mouse, a widely used species for modeling $\mathrm{SAE}$, the temperature range of standard practice in preclinical biomedical research [29] and legal recommendations [30] \{NRC, 2011 \#4699\} can be outside the thermoneutral zone for this species. Consequently, the aim of this study was to examine whether exposure of mice to $\mathrm{T}_{\mathrm{a}}$ outside their thermoneutral zone (but well within the practiced experimental guidelines) will affect $\mathrm{BBB}$ breakdown and brain inflammation triggered by LPS-induced systemic inflammatory response in mice. We hypothesized that a reduced $T_{a}$ exacerbates the inflammation-triggered BBB dysfunction at the system's, organ, and molecular levels. To examine different traits of PI3K $\gamma$ signaling on microglial activation, migration, and phagocytic activity, PI3K $\gamma$-deficient mice [31] and mice carrying a targeted mutation in the $\mathrm{PI} 3 \mathrm{~K} \gamma$ gene causing loss of lipid kinase activity [32] were habituated to neutral or reduced $\mathrm{T}_{\mathrm{a}}$. Subsequently, these animals were exposed to LPS to induce a systemic inflammatory response syndrome (SIRS). Our results demonstrate that challenging thermoregulation by exposure to reduced $T_{a}$ 
during SIRS causes enhanced early BBB breakdown. This $\mathrm{BBB}$ dysfunction is mediated by $\mathrm{PI} 3 \mathrm{~K} \gamma$-dependent microglial immune responses during acute systemic inflammation. Thus, preclinical research targeting severe brain inflammation responses is seriously biased when basic physiological prerequisites of mammal species such as preferred ambient temperature are ignored.

\section{Methods}

\section{Animals and experimental procedures}

PI3K $\gamma$ knockout mice $\left(\mathrm{PI} 3 \mathrm{~K}^{-1-}\right)$ [31] and mice carrying a targeted mutation in the PI3K $\gamma$ gene causing loss of lipid kinase activity (PI3K $\gamma^{\mathrm{KD} / \mathrm{KD}}$ ) [32] were on the C57BL/6 J background for $>10$ generations. Agematched C57BL/ 6 mice were used as controls. The animals were maintained at $12 \mathrm{~h}$ light and dark cycles with free access to food and water. The animal procedures were performed according to the guidelines from Directive 2010/63/EU of the European Parliament on the protection of animals used for scientific purposes. Experiments were approved by the committee of the Thuringian State Government on Animal Research.

In order to ensure appropriate acclimatization, animals were introduced at least 1 week before starting the interventions [33]. Animals were divided into a cohort kept at neutral ambient temperature $\left(29.5 \pm 0.5^{\circ} \mathrm{C}\right)$ [34] or another cohort kept at lowered ambient temperature $\left(29.5 \pm 0.5^{\circ} \mathrm{C}\right)$ during the whole experimental period for appropriate acclimatization. Therefore, mice cohorts were kept in housing cabinets equipped with humidity control, ambient temperature control, and a reliable day/ night cycle to ensure replicable environmental conditions (UniProtect; Fa. Ehret, Emmendingen, Germany). Then, mice received LPS $(10 \mathrm{mg} / \mathrm{kg}$, intraperitoneal, from Escherichia coli serotype 055:B5, Sigma-Aldrich, St. Louis, USA, Lot \#032M4082V) as a single intraperitoneal injection. Additionally, $500 \mu \mathrm{l}$ saline was injected subcutaneously immediately after LPS administration as well as after $24 \mathrm{~h}$ in order to support appropriate fluid resuscitation. Clinical status was assessed at baseline and $24 \mathrm{~h}$ after LPS administration according to [35].

As an in vitro correlate of hypothermia and neuroinflammation, primary microglia obtained from wild type, $\mathrm{PI} 3 \mathrm{~K}^{-1-}$, and PI3K $\gamma^{\mathrm{KD} / \mathrm{KD}}$ were exposed to an incubation temperature $\left(\mathrm{T}_{\text {Inc }}\right)$ of $33^{\circ} \mathrm{C}$ and LPS $(100 \mathrm{ng} / \mathrm{ml})$. (For overview, please refer to Table 1.)

\section{Telemetric assessment of body core temperature $\left(T_{C}\right)$ and heart rate}

$\mathrm{T}_{\mathrm{C}}$ and heart rate were assessed by telemetric monitoring of electrocardiography (ECG) and abdominal temperature.

Table 1 Overview of time course and experimental series

\begin{tabular}{|c|c|c|}
\hline Mice: & $\mathrm{Wt}, \mathrm{PI} 3 \mathrm{~K}^{-1}, \mathrm{PI} 3 \mathrm{~K}^{\mathrm{KD} / \mathrm{KD}}$ & $\begin{array}{l}\text { Cohort "Neutral } \mathrm{T}_{\mathrm{a}} \text { ": } \\
\text { Cohort "Reduced } \mathrm{T}_{\mathrm{a}} \text { ": }\end{array}$ \\
\hline
\end{tabular}

Animal experiments

Series

Series 1: Telemetry

\begin{tabular}{|c|c|c|c|}
\hline $\begin{array}{l}\text { Acclimatization } \\
\text { period }\end{array}$ & $\begin{array}{r}\text { Experime } \\
\text { (LPS injection } 10 \mathrm{n} \\
\text { Data accquis }\end{array}$ & $\begin{array}{l}\text { nt } \\
\text { g/kg, i.p.) } \\
\text { ition }\end{array}$ & Additional Procedures \\
\hline days & Baseline $3 \mathrm{~h}$ p.i. & 24h p.i. & $\begin{array}{r}\text { Transmitter implantation: } \\
>10 \text { days before } A p\end{array}$ \\
\hline days & Baseline & $24 h$ p.i. & EB (2\%) i.v.: 23 h p.i. \\
\hline days & Baseline $3 \mathrm{~h}$ p.i. & 24h p.i. & \\
\hline days & Baseline & $24 h$ p.i. & \\
\hline days & Baseline & 24h p.i. & Focal stab injury: 24 h p.i. \\
\hline days & Baseline & $24 h$ p.i. & Zymosan injection: 24 h p.i. \\
\hline
\end{tabular}

Cell culture experiments

Microglia obtained from $\mathrm{Wt}, \mathrm{PI} 3 \mathrm{~K}^{-1-}$, $\mathrm{PI} 3 \mathrm{~K}^{\mathrm{KD} / \mathrm{KD}}$ mice $(\mathrm{PO}-3)$

(Wt: Wild type mice (C57BL/6J strain), $\mathrm{PI} 3 \mathrm{~K}^{-1-}$ : PI3K $\gamma$ knockout mice, $\mathrm{PI} 3 \mathrm{~K} \gamma^{\mathrm{KD} / \mathrm{KD}}$ : mice carrying a targeted mutation in the $\mathrm{PI} 3 \mathrm{~K} \gamma$ gene causing loss of lipid kinase activity, $\mathrm{T}_{\mathrm{a}}$ : ambient temperature, LPS: lipopolysaccharide, EB: Evans blue, P0-3: 0-3 days after birth.) 


\section{Surgical procedure}

Mice were anesthetized with $2.5 \%$ isoflurane in oxygen. A midline incision was made on the abdomen, and the intraperitoneal cavity was gently opened. An implantable 1.6-g wireless radiofrequency transmitter (ETA-F10, Data Sciences International, St. Paul, MN) was inserted; the leads were transferred through the abdominal wall, and the incision was closed by a surgical suture. The cathodal lead was looped forward subcutaneously to an area overlying the scapula and anchored in place with a permanent suture. The anodal lead was brought subcutaneously to chest near the heart apex. Thereafter, skin incision was sutured. A warming light was used to maintain body temperature between 36 and $37^{\circ} \mathrm{C}$. Meloxicam was given for pain on the day of surgery and the following day. Experiments were initiated 10 days after recovery from surgical instrumentation. Animals were monitored continuously by telemetry by ECG as well as body temperature and motor activity recording.

\section{Data acquisition and processing}

For simultaneous ECG and body temperature, analog signals were digitalized by the telemetric receiver (model RPC-1, Data Sciences International, St. Paul, MN) and transferred via DSI Data Exchange Matrix at a sampling rate of $2 \mathrm{kHz}$ with 12-bit precision (acquisition software: Ponemah Software 5.20) without a signal filter, and stored on PC for offline data analysis. Instantaneous heart rate $(\mathrm{HR})$ was derived from the reciprocal $R R$ interval time series. Therefore, the individual $\mathrm{R}$-waves, with the R-wave peak as the trigger point, were sequentially recognized (ATISApro ${ }^{\circ}$, GJB Datentechnik $\mathrm{GmbH}$, Langewiesen, Germany). Accurate R-wave peak detection was verified by visual inspection. Temperature was continuously measured by the implanted transmitter and stored in parallel to the ECG signal.

\section{Measurement of blood-brain barrier permeability}

$\mathrm{BBB}$ disruption was analyzed by measurement of Evans blue (EB) extravasation into brain tissue as described previously $[5,36]$. In brief, EB $(4 \mathrm{ml} / \mathrm{kg}$ of a $2 \%$ solution in PBS) was injected through the tail vein $1 \mathrm{~h}$ prior to killing. Deeply anesthetized animals were transcardially perfused with ice-cold PBS $(40 \mathrm{ml}) 24 \mathrm{~h}$ after LPS administration. The brains were removed after blood removal, snap-frozen in liquid nitrogen, and stored at $80^{\circ} \mathrm{C}$. One hemisphere was homogenized in trichloroacetic acid $(50 \%)$ and centrifuged $(10,000 \mathrm{rpm}$, $20 \mathrm{~min}, 4{ }^{\circ} \mathrm{C}$ ). Supernatant was diluted in three volumes of ethanol. EB was quantified by fluorescence measurement (Tecan Infinite F200, excitation 620 nm, emission $670 \mathrm{~nm}$ ) and compared to a standard curve. EB concentrations are presented as microgram of EB per microliter of brain tissue supernatant.
Blood and brain tissue cytokine assessment

The cytokine levels (TNF- $\alpha$, IL-6, MCP-1, IL-10) in blood and brain tissues were determined using $\mathrm{BD}^{\mathrm{ms}}$ CBA Mouse Inflammation Kit (Dickinson and Company, San Jose, USA). Blood was obtained via direct heart puncture, collected in a heparinized syringe and immediately centrifuged at $1500 \times \mathrm{g}$ for $10 \mathrm{~min}$ at $4{ }^{\circ} \mathrm{C}$. The plasma supernatant was taken immediately and kept at $80^{\circ} \mathrm{C}$ until measurement. The brain tissue was harvested after rinsing with cold PBS, immediately put in liquid nitrogen, and kept at $-80^{\circ} \mathrm{C}$ until processing. The brain tissue was then powdered, ice-cold diluted in PBS, homogenated, and centrifuged at $1000 \mathrm{~g}$ for $10 \mathrm{~min}$ at $4{ }^{\circ} \mathrm{C}$. Supernatant was immediately kept at $-80^{\circ} \mathrm{C}$ until measurement.

\section{Primary microglial cell isolation procedure}

Neonatal primary microglial cells were isolated from cerebral cortex of newborn mice (6-12 newborn male and female mouse brains were pooled, respectively) as described previously $[8,37,38]$. Briefly, newborn mice were decapitated, and heads were transferred into Petri dishes filled with ice-cold phosphate-buffered saline (PBS). Using fine scissors, the scalp was opened carefully along midline, and the brain was removed. Then, meninges were removed, and cortices and hippocampi were collected in 15-ml tubes filled with PBS. Collected brains were processed in $2 \mathrm{ml}$ dissociation media containing $200 \mu \mathrm{l} 2.5 \%$ trypsin and further supplemented with $20 \mu \mathrm{l}$ of DNAse I in order to digest DNA released from dead cells. After incubation at $37^{\circ} \mathrm{C}$ and $5 \% \mathrm{CO}_{2}$ for $30 \mathrm{~min}$, the medium was removed, and the brain tissues were suspended in $2 \mathrm{ml}$ of Dulbecco's Modified Eagle's medium (DMEM, SIGMAAldrich \#06429, endotoxin tested) containing 10\% heatinactivated fetal bovine serum (FBS, SIGMA-Aldrich \#F7524, endotoxin-free and sterile-filtered), 1\% Penicillin/ Streptomycin, 1\% amphotericin B, supplemented with $30 \mu \mathrm{l}$ DNAse I. Brain tissues were then homogenized and further transferred to T75 cell culture flasks with additional $8 \mathrm{ml}$ culture medium and incubated in $37^{\circ} \mathrm{C}$ and $5 \% \mathrm{CO}_{2}$ for 7 days, followed by medium change and further incubation for 7 more days.

After 14 days, adherent microglial cells were separated from astrocytes by adding PBS-EDTA solution and careful shaking. After harvesting, microglial cells were seeded $(75,000$ cells/well) in adherent well plates. Purity of microglial cells was between 94 and $98 \%$, as confirmed by the specific Iba1 staining (Suppl. Fig.1). This cell yield and purity are similar to those obtained in previous studies $[23,25]$.

\section{RNA extraction and CDNA synthesis}

For quantification of mRNA, cells were seeded into 6well plates and incubated at $37^{\circ} \mathrm{C}\left(5 \% \mathrm{CO}_{2}\right)$ overnight. 
Afterwards, cells were disintegrated in Trizol reagent (QIAzol Lysis Reagent (\#79306), Qiagen, Hilden, Germany). Total RNA was extracted from Trizol as recommended by the manufacturer. To prevent contamination of mRNA preparation with chromosomal DNA, mRNA samples were treated with DNase. RNA amount and purity were determined by Nano-DropTM 1000 (Peqlab, Erlangen, Germany). For first strand cDNA synthesis, $1 \mu \mathrm{g}$ total RNA was employed using the RevertAid First Strand cDNA Synthesis kit (\#K1612) from Thermo Fisher Scientific (Waltham, MA, USA). Synthesis followed the protocol recommended by the manufacturer.

\section{Quantitative PCR}

Quantitative PCR (qPCR) was performed with Maxima SYBR Green/ROX qPCR Master Mix Kit (Fermentas; St. Leon Rot, Germany) containing Maxima Hot Start Taq DNA polymerase and appropriate primer pairs. The following primer pairs were used: MMP-2 forward: TGGCAGTGCAATACCTGAAC and MMP-2 reverse: CCGTACTTGCCATCCTTCTC; MMP-3 forward: GTACCAACCTATTCCTGGTTGC and MMP-3 reverse: CCAGAGAGTTAGATTTGGTGGG; MMP-9 forward: ACCACTAAAGGTCGCTCGGATGGTT, MMP9 reverse: AGTACTGCTTGCCCAGGAAGACGAA; MMP-13 forward: GGGCTCTGAATGGTTATGACAT TC, MMP-13 reverse: AGCGCTCAGTCTCTTCACCTCT T; and GAPDH forward: CATGGCCTTCCGTGTTTC CTA and GAPDH reverse: CCTGCTTCACCACCTTCT TGAT. Relative mRNA expression was calculated in relation to mRNA levels of the housekeeping gene, GAPDH, according to 2- $\Delta \Delta C$ T method [39].

\section{In vitro chemotaxis assay}

To investigate the influence of lipid kinase-dependent and kinase-independent functions of $\mathrm{PI} 3 \mathrm{~K} \gamma$ on microglial migration, transwell assays were performed. Cells were seeded in 6-well plates. After attachment, cells were starved and incubated with intended substances. Following stimulation, $1 \times 10^{5}$ cells were transferred in $300 \mu \mathrm{l}$ serum-free medium into the upper chamber of a 12-well chemotaxis insert (ThinCertTM, $8 \mu \mathrm{m}$ pores; Greiner-Bio-One GmbH, Frickenhausen, Germany). The chamber was placed in $700 \mu \mathrm{l}$ serum-free medium containing chemoattractant $(\mathrm{C} 5 \mathrm{a} ; 10 \mathrm{ng} / \mathrm{ml})$ and incubated at $37^{\circ} \mathrm{C}$ (normal $\mathrm{T}_{\text {Inc }}$ ) or at $33^{\circ} \mathrm{C}$ (reduced $\mathrm{T}_{\text {Inc }}$ ) with $5 \%$ $\mathrm{CO}_{2}$ for $2 \mathrm{~h}$. Afterwards, cells on the lower side of the insert membrane were fixed with $100 \%$ ice-cold methanol and stained with $0.5 \%$ crystal violet solution (in 25\% methanol) for $10 \mathrm{~min}$. Average count of migrated cells was estimated through consideration of five independent visual fields.

\section{In vivo microglial migration assay}

Experiments were performed on adult (10-14 weeks) wild type, PI $3 \mathrm{~K}^{-1-}$, and $\mathrm{PI} 3 \mathrm{~K} \gamma^{\mathrm{KD} / \mathrm{KD}}$ mice (7 mice per group) kept during the whole experimental period at neutral $T_{a}$ or reduced $T_{a}$, respectively. To investigate the effect of targeted PI3K $\gamma$ mutation on microglial migration at neutral or reduced $\mathrm{T}_{\mathrm{a}}$, an in vivo wound-healing experiment was performed. Mice were anesthetized by intraperitoneal injection of ketamine $(100 \mathrm{mg} / \mathrm{kg})$ and xylazine $(16 \mathrm{mg} / \mathrm{kg})$, and positioned in a stereotaxic apparatus (Stoelting, Wood Dale, IL, USA). Mice were then placed on a homeothermic heat blanket to maintain normal body temperature during surgery. The skull was exposed by a skin incision, and small burr holes were drilled through the skull. Using a micromanipulator focal stab, an injury was performed by gentle insertion of stainless steel pin (diameter $0.25 \mathrm{~mm}$ ) into the parietal cortex at $3 \mathrm{~mm}$ below the dura mater [40,41]. The pin was kept in place for $2 \mathrm{~min}$ and then removed. The burr holes were covered with bone wax, and the animals were returned to their cages. Twelve hours later, mice were deeply anesthetized and perfused with $4 \%$ paraformaldehyde (PFA) in phosphate buffer by cardiac puncture via the left ventricle. Brains were removed immediately after fixation and post-fixed for $5 \mathrm{~h}$ in $4 \%$ PFA at $4{ }^{\circ} \mathrm{C}$. After cryoprotection in phosphatebuffered saline (PBS) containing 30\% sucrose, brains were frozen in methylbutane at $-30{ }^{\circ} \mathrm{C}$ and stored at $-80{ }^{\circ} \mathrm{C}$. Whole brains were cut by horizontal sections at $40 \mu \mathrm{m}$ on a freezing microtome (Microm International $\mathrm{GmbH}$, Thermo Scientific, Germany). The slices were immunostained with anti-Ibal antibody to visualize microglia. Sections were photographed with a digital fluorescence camera (Nikon DSQi2) and mounted on the Nikon inverted research microscope Eclipse $\mathrm{Ti}$ (Nikon Instruments Europe B.V., Amstelveen, The Netherlands). Quantitative measurements (ImageJ software, National Institutes of Health, Bethesda, MD) blinded to the treatment groups were used to count cell numbers per voxel and expressed in cubic millimeter. At the injured region, three voxels were predefined as follows: voxel 1 , a cylinder with a diameter of $400 \mu \mathrm{m}$, center lying in the middle of injury, and an altitude of $40 \mu \mathrm{m}$; voxel 2, hollow cylinder, subsequently on voxel 1 , with an inner diameter of $400 \mu \mathrm{m}$, an outer diameter of $800 \mu \mathrm{m}$, and an altitude of $40 \mu \mathrm{m}$; voxel 3, hollow cylinder, subsequently on voxel 2 , with an inner diameter of $800 \mu \mathrm{m}$, an outer diameter of $1200 \mu \mathrm{m}$, and an altitude of $40 \mu \mathrm{m}$. Number of Iba1-positive cells was counted in all three voxels. Migratory index was estimated as the ratio of cell number in voxel 1 divided by the sum of cell number in voxels 1,2 , and 3 as described previously [40, 42]. 


\section{In vitro phagocytosis assay}

Efficiency of phagocytosis at reduced versus neutral $\mathrm{T}_{\mathrm{a}}$ was investigated as previously described [40,42]. Briefly, primary microglia cells obtained from wild type, $\mathrm{PI} 3 \mathrm{~K}^{-1-}$, and $\mathrm{PI} 3 \mathrm{~K} \gamma^{\mathrm{KD} / \mathrm{KD}}$ mice were seeded into 12well plates and incubated at $37^{\circ} \mathrm{C}\left(5 \% \mathrm{CO}_{2}\right)$ for $24 \mathrm{~h}$. After attachment, cells were starved for $24 \mathrm{~h}$ in DMEM without FCS. Cell were subsequently stimulated with LPS $(100 \mathrm{ng} / \mathrm{ml})$ or left unstimulated. Phagocytosis assay was performed by using fluorescein isothiocyanate (FITC)-labeled Zymosan A (S. cerevisiae) BioParticles $(9800 \mathrm{U} / \mathrm{ml}) \quad$ (\#Z2841, Thermo Fisher Scientific, Waltham, USA). Seven microliters of the suspended particles was added to the microglial cells and incubated $1 \mathrm{~h}$ at either $37^{\circ} \mathrm{C}$ or $33^{\circ} \mathrm{C}$. After incubation, the cells were fixed with $4 \%$ PFA, washed three times, and stained with DAPI-solution for 5 min (1:1000 in 1× PBS). Phagocytosed particles and cells of five independent visual fields were counted under a fluorescence microscope (Nikon Eclipse Ti, Nikon Instruments-Japan). The result of the phagocytosis of primary microglia was calculated by determining the phagocytic index (the uptake rate of FITC-Zymosan particles per cell).

\section{In vivo phagocytosis assay}

Experiments were performed on adult (10-14 weeks) wild type, $\mathrm{PI} 3 \mathrm{~K}^{-/-}$, and $\mathrm{PI} 3 \mathrm{~K} \gamma^{\mathrm{KD} / \mathrm{KD}}$ mice $(7$ mice per group) kept during the whole experimental period at neutral $\mathrm{T}_{\mathrm{a}}$ or reduced $\mathrm{T}_{\mathrm{a}}$, respectively. To investigate the effect of targeted PI3Ky mutation on microglial phagocytosis, FITC-labeled Zymosan particles $(9800 \mathrm{U} / \mathrm{ml})$ were administered into the brain as described previously [40]. Briefly, mice were anesthetized by intraperitoneal injection of ketamine $(100 \mathrm{mg} / \mathrm{kg})$ and xylazine $(16 \mathrm{mg} /$ $\mathrm{kg}$ ), and positioned in a stereotaxic apparatus (Stoelting, Wood Dale, IL, USA). The skull was exposed by a skin incision, and small burr holes were drilled through the skull. Using a micromanipulator, a cannula (diameter $0.24 \mathrm{~mm})$ attached on a Hamilton microsyringe $(10 \mu \mathrm{l})$ was stereotaxically placed into the parietal cortex on both sides (stereotaxic coordinates were AP, $-2.0 \mathrm{~mm}$; $\mathrm{L}, \pm 0.5 \mathrm{~mm}$; and V, $-2.5 \mathrm{~mm}$, respectively [43]). Subsequently, $4 \mu \mathrm{l}$ of FITC-labeled Zymosan particles suspended in artificial cerebrospinal fluid were infused within $120 \mathrm{~s}$. The cannula remained in place for $5 \mathrm{~min}$ before removal. Twenty-four hours later, mice were deeply anesthetized and perfused with $4 \%$ PFA in phosphate buffer by cardiac puncture via the left ventricle. Brains were removed immediately after fixation and post-fixed for $5 \mathrm{~h}$ in $4 \%$ PFA at $4{ }^{\circ} \mathrm{C}$. After cryoprotection in PBS containing $30 \%$ sucrose, brains were frozen in methylbutane at $-30^{\circ} \mathrm{C}$ and stored at $-80^{\circ} \mathrm{C}$. Whole brains were cut by coronal sections at $40 \mu \mathrm{m}$ on a freezing microtome (Microm International $\mathrm{GmbH}$, Thermo
Scientific, Germany). The slices were immunostained with anti-Ibal antibody to visualize microglia. A voxel with an edge length of $400 \mu \mathrm{m}$ and an altitude of $40 \mu \mathrm{m}$ were predefined as region of interest. Z-stack imaging was performed with $\mathrm{a} \times 20$ objective using a digital fluorescence camera (Nikon DS-Qi2), mounted on the Nikon inverted research microscope Eclipse Ti (Nikon Instruments Europe B.V., Amstelveen, The Netherlands). Quantitative measurements (ImageJ software, National Institutes of Health, Bethesda, MD) blinded to the treatment groups were used to count the percentage number of Iba-1 positive cells per cubic millimeters containing Zymosan particles.

\section{Histopathology and immunohistochemistry}

For determination of microglial activation, PMN homing, MMP-9 expression, and TUNEL positivity, brains were fixated in situ by transcardial perfusion with $4 \%$ PFA after rinsing with PBS. Afterwards, they were immediately removed after fixation, post-fixated in $4 \%$ PFA at $4{ }^{\circ} \mathrm{C}$ for 1 day, embedded in paraffin, and cut into 6 $\mu \mathrm{m}$-thick sections. After deparaffinization, the sections were heated with citrate buffer $(0.01 \mathrm{M}, \mathrm{pH} 6.0)$ in the microwave $(630 \mathrm{~W}, 11 \mathrm{~min})$ for antigen removal, and the nonspecific binding sites were blocked with blocking solution ( $5 \%$ NDS, $1 \%$ BSA-c, PBST). Then, the slidemounted tissue sections were incubated with the desired primary antibody in antibody incubation solution $(5 \%$ NDS, $1 \%$ BSA-c, PBST) at $4{ }^{\circ} \mathrm{C}$ overnight, followed by an incubation with the associated secondary antibody at $4{ }^{\circ} \mathrm{C}$ for $1 \mathrm{~h}$. Negative control sections were incubated with goat serum in the absence of the primary antibody. The following primary antibodies were used: goat polyclonal anti-Iba-1 (1:250) antibody (Abcam, Cambridge, UK) for Iba1 staining, rabbit polyclonal anti-MMP-9 (1: 150) antibody (Cell Signaling Technology, Danvers, USA) for MMP-9, and rabbit anti-mouse PMN (Accurate Chemical \& Scientific CO, USA) for neutrophil staining. For visualization, the secondary fluorescent goat anti-mouse isotype-specific antibody Alexa Fluor ${ }^{\circ} 488$ (Molecular Probes, Inc., Eugene, USA) and donkey antigoat IgG antibody Alexa Fluor 568 (Thermo Fisher Scientific, Waltham, USA) were used. Method for TUNEL staining was described elsewhere [44]. Briefly, sections were deparaffinized and prepared for TUNEL-staining. Fragmented DNA was detected in situ by the TUNEL method using a commercially available kit according to the manufacturer's protocol (In Situ Cell Death Detection Kit, POD; Roche, Germany). Deparaffinized sections were pretreated with $20 \mathrm{mg} / \mathrm{ml}$ proteinase $\mathrm{K}$ and washed in PBS prior to TUNEL staining. TUNEL staining was performed by incubation with fluorescein-conjugated digoxigenin-UTP and terminal deoxynucleotidyltransferase at $37^{\circ} \mathrm{C}$ for $1 \mathrm{~h}$. DNA fragmentation was visualized 
using converter-alkaline phosphatase, NBT/BCIP, and counterstaining with Kernechtrot.

\section{Cell counting for assessment of microglial cell activation} Cells were classified as ramified, amoeboid, unipolar, and bipolar. Ramified (normal) microglial cells are defined by thin, slender, radially projecting processes with well-developed ramifications. Amoeboid microglial cells are defined as having large soma, and short, thick, and radially projecting processes. Unipolar and bipolar microglial cells were defined as having one or two thick process with well-developed ramifications [14, 45]. Estimation of cell counting migration and phagocytic index were performed by a co-author (G.-P. L.) blinded for genotype and treatment. In each case, evaluation was performed on three different slices obtained from the frontal cortex, thalamus, and hippocampus, each. Five separate fields of vision were counted with at least 100 cells.

\section{Statistics}

The statistical analysis was performed using the SigmaPlot Software (Sigma-Plot Software, San Jose, USA). All data are presented as boxplots illustrating medians within boxes from first quartile (25th percentile) to the third quartile (75th percentile) and whiskers ranging from the 10th to the 90th percentiles (extreme values are marked outside). Numbers of animals are given in figure legends for each group and time point. Comparisons between groups were made with one-way or twoway analysis of variance, if appropriate. In case of repeated measurements, one-way and two-way analysis of variance with repeated measures was used, if appropriate. Post hoc comparisons were made with the HolmSidak test or $t$ tests with Bonferroni's correction for adjustments of multiple comparisons. Data not following normal distribution was tested with Kruskal-Wallis test followed by Dunn's multiple comparisons test.

\section{Results}

Impact of ambient temperature on degree of SIRS and SIRS-induced BBB disturbance

Intraperitoneal LPS administration induced a robust SIRS in mice kept under neutral as well as reduced $T_{a}$ as revealed by cytokine release in blood plasma and brain tissue (Fig. 1). IL-10 anti-inflammatory response was barely developed. However, reduced $\mathrm{T}_{\mathrm{a}}$ induced a worsened sickness state of SIRS in PI3K $\gamma$-deficient mice as measured by the clinical severity score (Tabl.1 Suppl.).

Telemetric $\mathrm{T}_{\mathrm{C}}$ monitoring revealed that under baseline conditions, all mice, regardless $T_{a}$, showed no differences in body temperature. However, reduced $\mathrm{T}_{\mathrm{a}}$ was accompanied by an enhanced sympathetic tone to the heart already under baseline conditions, indicated by an increased HR regardless of the genotype (Fig. 2). Importantly, whereas the early period of LPS-induced SIRS was characterized by a rather similar HR elevation, HR remained elevated in the animals kept under neutral $T_{a}$, but not in the animals kept under reduced $T_{a}$, throughout the observation period. Furthermore, all mice kept under neutral $\mathrm{T}_{\mathrm{a}}$ exhibited a short-term period of mild hypothermia whereas the mice kept under reduced $T_{a}$ developed a markedly more pronounced and longer (24 $\mathrm{h}$ versus $12 \mathrm{~h}$ ) lasting hypothermic period (Fig. 2).

Under neutral $\mathrm{T}_{\mathrm{a}}$, LPS-induced SIRS provoked an increase of BBB leakage in wild type mice, whereas PI3K $\gamma$ deficient mice exhibited a significantly enhanced BBB disturbance compared with wild-type mice (Fig. 3). At baseline, this was also true for PI3K $\gamma$-kinase-dead mice.

In contrast, at baseline, housing under reduced $T_{a}$ induced BBB leakage in wild-type mice to a similar degree as in the mutant mice (Fig. 3b). Moreover, already at baseline, in the wild-type mice, the BBB leakage was more pronounced at reduced $\mathrm{T}_{\mathrm{a}}$ than at neutral $\mathrm{T}_{\mathrm{a}}$. LPSinduced SIRS provoked a substantially enhanced BBB leakage, which was most pronounced in PI3K $\gamma$-deficient mice. Of note, lipid kinase-dead mutant mice display similar degree of BBB breakdown as the wild-type mice indicating a causal impact of lipid kinase-independent PI3K $\gamma$ signaling on the development of BBB disturbance during SIRS.

\section{Impact of $T_{a}$ and SIRS on degree of microglial activation, MMP expression, apoptosis, and PMN invasion}

To verify consequences of $\mathrm{T}_{\mathrm{a}}$ and LPS-induced SIRS, extent of neuroinflammation was assessed by different approaches. First, we quantified the number of activated microglial cells assessed by shape characteristics [45]. As shown in Fig. 4 and Fig. 2 Suppl., a marked increase in microglial cell number with altered, mainly polarized shape occurred. Analysis of regional distribution revealed similarity in the extent of regional microglial cell activation in the brain cortex, hippocampus, and thalamus (Tabl. 2 Suppl.) suggesting a diffuse microglial activation due to LPS-induced SIRS. While we did not observe a significant genotype-related effect, the wildtype mice showed an exacerbated response with regard to activated microglia counts at reduced $\mathrm{T}_{\mathrm{a}}$.

In contrast, MMP expression in brain tissue obtained $24 \mathrm{~h}$ after LPS injection displayed a significant $\mathrm{T}_{\mathrm{a}}$ as well as PI3KY dependency. There was an enhanced RNA expression in the brains obtained from $\mathrm{PI} 3 \mathrm{~K} \gamma$-deficient mice kept under reduced $T_{a}$ in all MMPs under consideration compared to mice kept under neutral $\mathrm{T}_{\mathrm{a}}$ (Fig. 5). Furthermore, there was an increased mRNA expression in brains derived from PI3K $\gamma$-deficient mice kept under reduced $\mathrm{T}_{\mathrm{a}}$ compared with wild-type mice kept under same housing conditions. In contrast, $\mathrm{PI} 3 \mathrm{~K} \gamma^{\mathrm{KD} / \mathrm{KD}}$ mice 


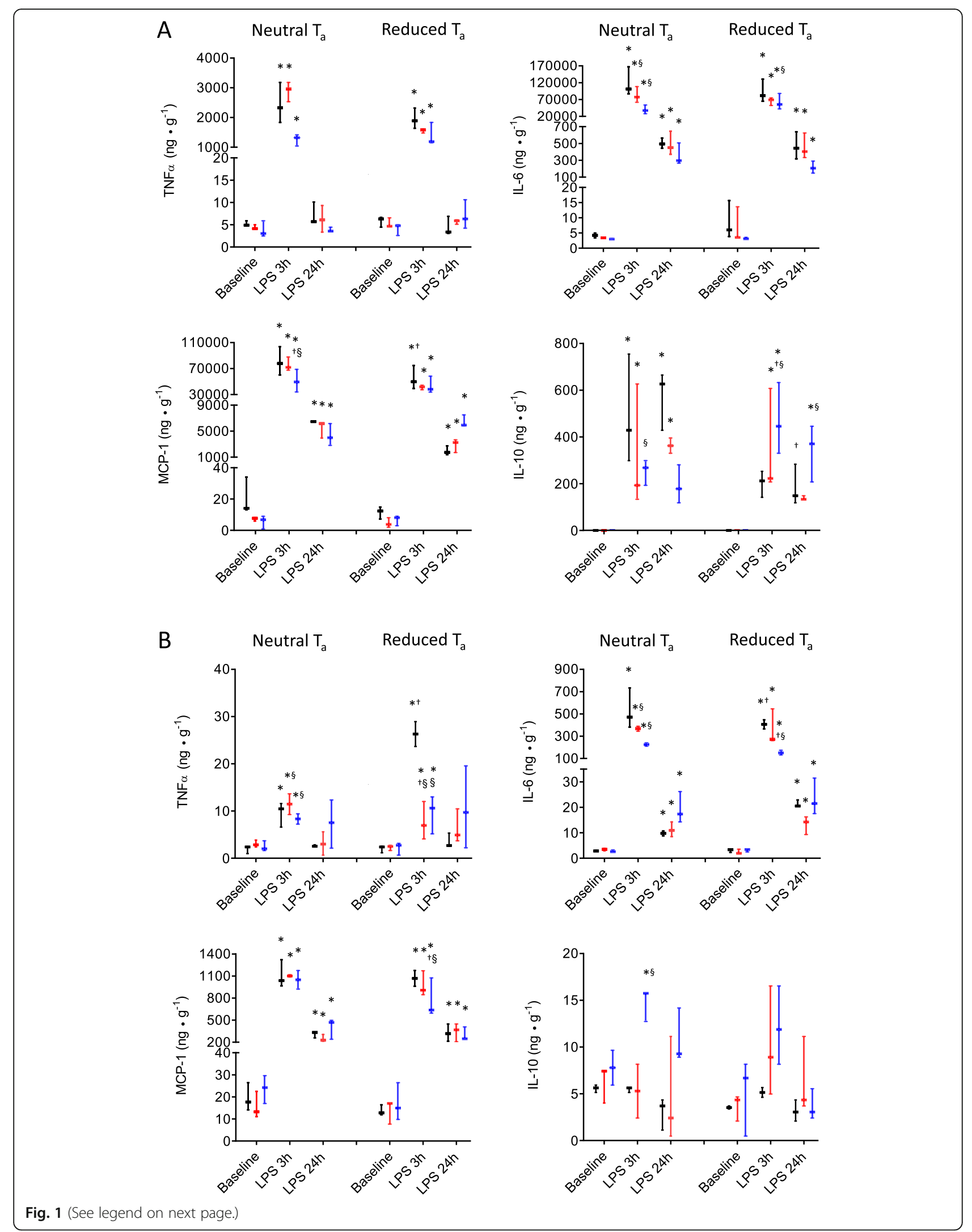


(See figure on previous page.)

Fig. 1 Cytokine levels in blood plasma (a) and brain tissue (b). Values are given as medians and whiskers (minimum and maximum), $n=3$, for each group and experimental state. ${ }^{*} \S p<0.05$, asterisk indicates significant differences versus baseline conditions within the same genotype, dagger sign significant differences versus neutral Ta within the same genotype, section sign indicates significant differences versus wild-type (Wt) mice within the same Ta condition

showed a similar response as wild-type mice, again suggesting a lipid kinase-independent mode of action.

Increased cerebral MMP expression appeared as a result of enhanced microglial activation in $\mathrm{PI} 3 \mathrm{~K}^{-1-}$ mice kept under reduced $\mathrm{T}_{\mathrm{a}}$ as is evidenced by an increased number of MMP-9 positive cells co-expressed in Iba-1 positive cells in these brains (Fig. 6a). Analysis of regional distribution revealed similarity in the extent of microglial MMP-9 expression in the brain cortex, hippocampus, and thalamus (Tabl. 3 Suppl.), again suggesting a uniform increase in activity.
To examine a possible $\mathrm{T}_{\mathrm{a}}$-dependent impact on structural integrity of brain tissue due to LPS-induced SIRS, we quantified the extent of apoptosis in brain slices derived from wild type, PI $3 \mathrm{~K}^{-/-}$, and PI3K $\gamma^{\mathrm{KD} / \mathrm{KD}}$ mice kept under neutral and reduced $\mathrm{T}_{\mathrm{a}}$. Albeit of small magnitude, already under baseline conditions, the rate of apoptotic cells was significantly increased in brains of PI3 $\mathrm{K}^{-1-}$ mice kept under reduced $\mathrm{T}_{\mathrm{a}}$ compared with those kept at neutral $\mathrm{T}_{\mathrm{a}}$. LPS-induced SIRS exhibited consistently an increased number of apoptotic cells, which was most pronounced in $\mathrm{PI} 3 \mathrm{~K}^{-/-}$mice kept

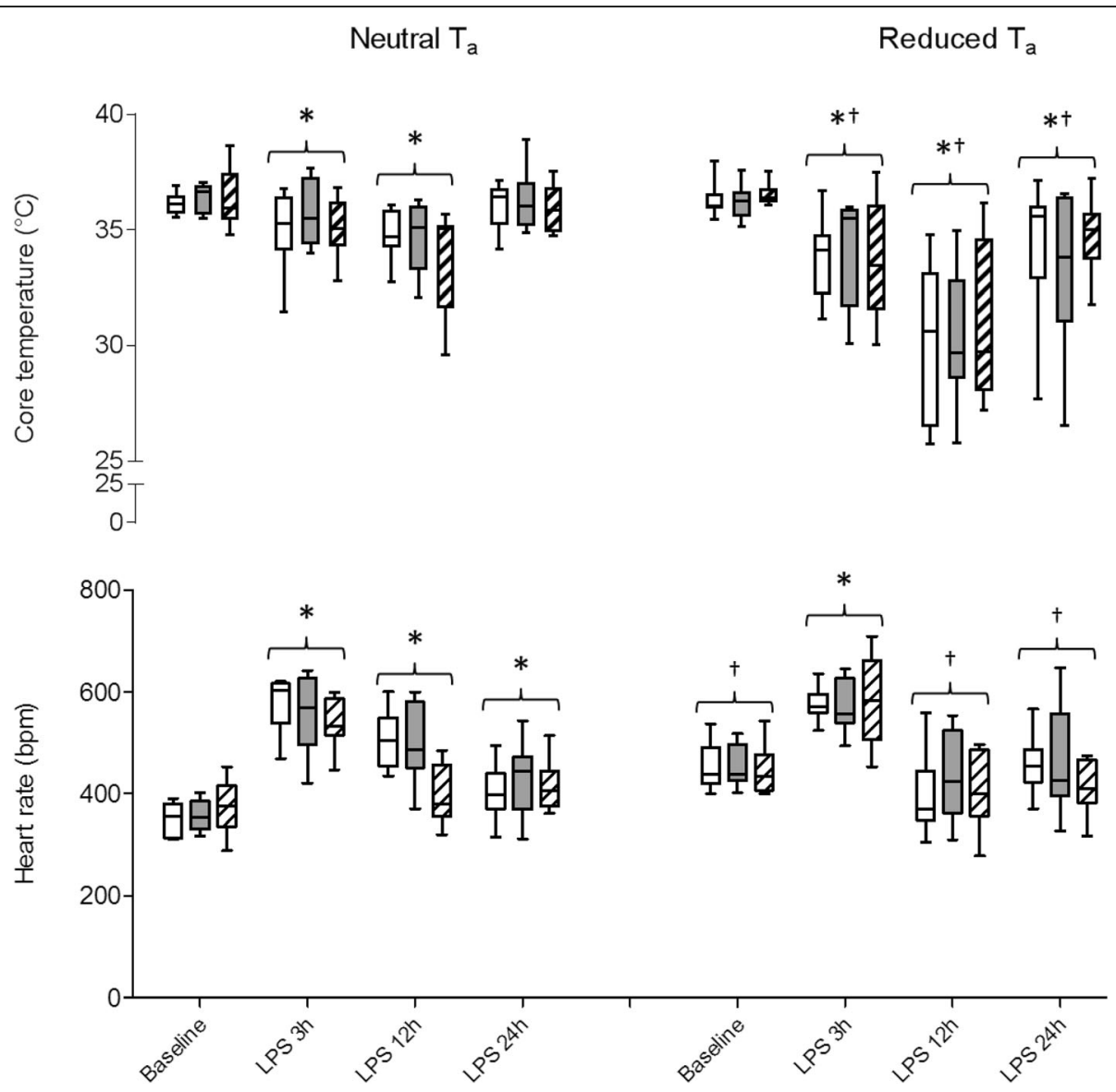

Fig. 2 Altered heart rate and augmented hypothermia in mice kept under reduced ambient temperature $\left(T_{a}\right)$ after LPS-induced SIRS response compared with mice kept under neutral $\mathrm{T}_{\mathrm{a}}$ irrespective of the genotype (wild-type mice, open boxplots, PI3KY-deficient mice $\left(\mathrm{PI} 3 \mathrm{KY}^{-1-}\right.$ ) filled boxplots, PI3KY-kinase-dead mice (PI3KY KD/KD) hatched boxplots). Values are presented as boxplots illustrating medians within boxes from first quartile to the third quartile, whiskers ranging from the 10th to the 90th percentiles (neutral Ta groups: wild-type mice $n=9, \mathrm{PI} 3 \mathrm{~K} \gamma^{-1-} n=10$, $\mathrm{PI} 3 \mathrm{KK}{ }^{\mathrm{KD} / \mathrm{KD}}, n=8$; reduced $\mathrm{T}_{\mathrm{a}}$ groups: wild-type mice $\left.n=12, \mathrm{PI} \mathrm{K}^{-1-} n=10, \mathrm{PI} \mathrm{KK} \mathrm{K}^{\mathrm{KD} / \mathrm{KD}} n=9\right)$. ${ }^{*} p<0.05$, asterisk indicates significant difference between baseline and LPS stimulation within each $T_{a}$ state, dagger sign significant differences versus mice kept under neutral $T_{a}$ (twoway repeated measures ANOVA, followed by Holm-Sidak test for post hoc multiple comparisons were performed) 


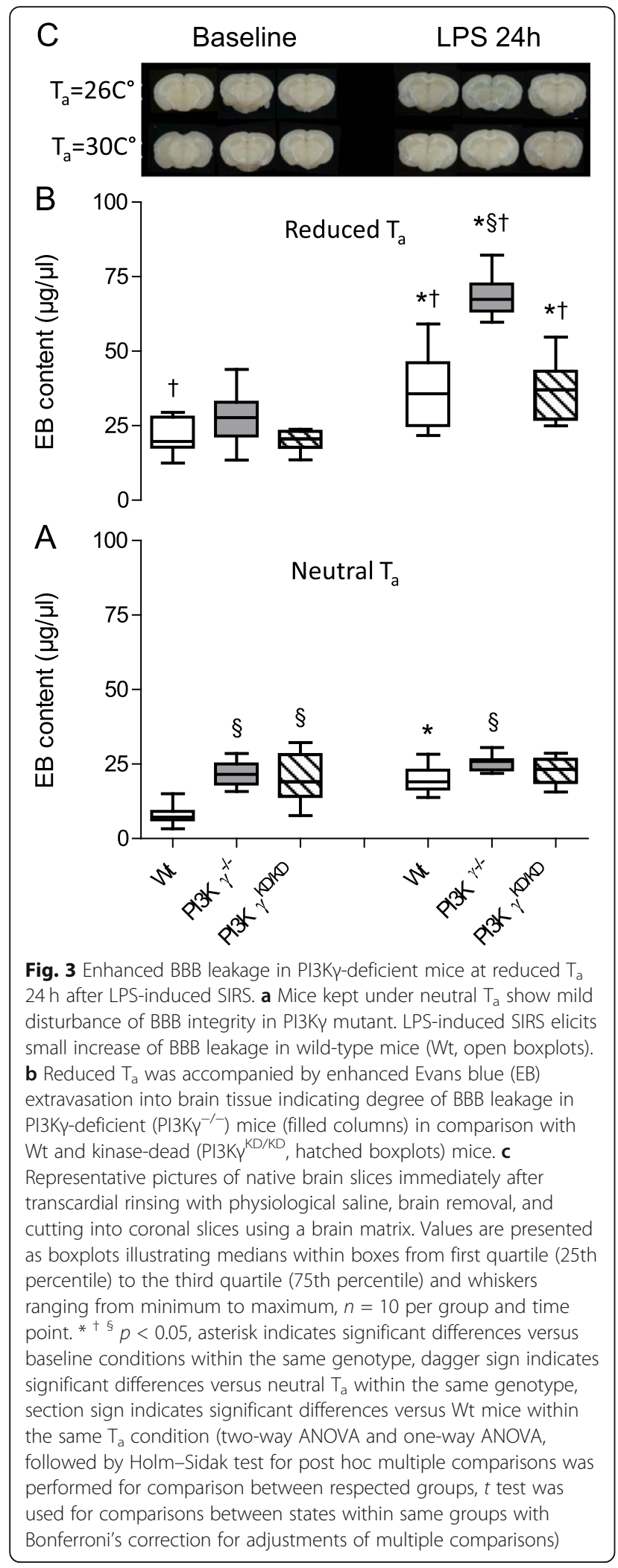

under reduced $\mathrm{T}_{\mathrm{a}}$ (Fig. 6b, Fig. 3 Suppl.). Regional comparison revealed that numbers of TUNEL-positive cells in PI3 $\mathrm{K}^{-1-}$ mice kept under reduced $\mathrm{T}_{\mathrm{a}}$ were markedly higher in the hippocampus compared to cortex and thalamus (Tabl. 3 Suppl.).

To assess a contribution of blood-born immune cells to pathogenesis of SIRS-induced SAE, we quantified the extent of invading PMN. Whereas under baseline conditions, merely scattered PMN were encountered, and neither $\mathrm{T}_{\mathrm{a}}$ nor genotype-related effects have been observed; LPS-induced SIRS was accompanied by a distinct increase of invading PMN into the brain tissue. We found a significant $\mathrm{T}_{\mathrm{a}}$-dependent effect in PI3K $\gamma$-deficient mice observing an enhanced PMN homing into brain tissue in mice kept under reduced $\mathrm{T}_{\mathrm{a}}$ (Fig. 6c, Fig. 3 Suppl.). However, consistent with findings for Iba1-positive microglia cell numbers and MMP expression, we observed no brain regional differences in PMN invasion (Tabl. 3 Suppl).

\section{Impact of $T_{a}$ incubation temperature on microglial migration and phagocytosis}

The ability to migrate toward different chemotactic stimuli including those released by brain injuries is an important property of microglial cells, which is essential for biological functions. Our previous studies revealed a dependency of lipid kinase-related PI3KY signaling on directed motility of microglial cells owing to inflammatory stimulation [40]. Herein, we addressed the question if PI3K $\gamma$-dependent migration of microglia is a result of different ambient temperatures and its in vitro surrogate, i.e., the varied temperatures of incubation $\left(\mathrm{T}_{\text {Inc }}\right)$.

First, the in vitro cell motility was quantified toward migration to $\mathrm{C} 5$ a added to bottom well of the transwell assay together with LPS stimulation. C5a acts as inflammatory peptide resulting in stimulation of microglial migration toward this chemo attractant. As demonstrated in Fig. 7a, PI3K $\gamma$ - deficiency as well as targeted knockout of the lipid kinase activity of PI3KY caused a markedly reduced migratory capacity by about $50 \%$ compared with cells derived from wild-type mice. A moderately reduced $\mathrm{T}_{\text {Inc }}$ provoked a further reduction in directed motility of primary microglial cells, whereas the PI3K $\gamma$ related migratory alteration remained preserved.

To assess the effect of PI3K $\gamma^{-}$deficiency on directed cell motility in vivo, a wound healing assay using focal stab-injury [40] was carried out. Whereas the baseline number of microglial cells was similar in wild type, PI3K $\gamma$ deficient, and PI3K $\gamma$-kinase dead brains (Table 4 Suppl.), migration of microglia in direction of the focal stab injury was clearly reduced in the brains from $\mathrm{PI} 3 \mathrm{~K} \gamma$ mutants as indicated by reduced microglial cell numbers in the inner region of interest (see Fig. 7a, Suppl. Fig. 4) of the injury site, which was markedly reduced in mice 


\section{B}

Baseline

LPS $24 \mathrm{~h}$

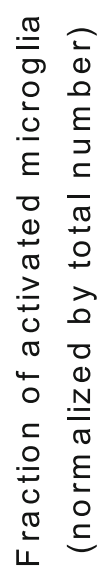

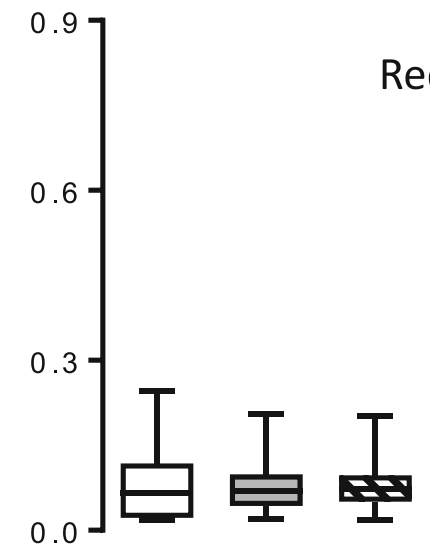

\section{Reduced $\mathrm{T}_{\mathrm{a}}$}

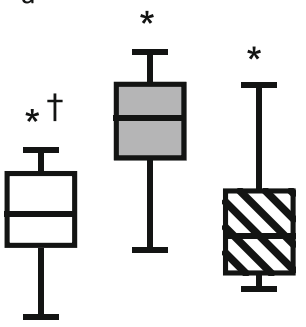

A

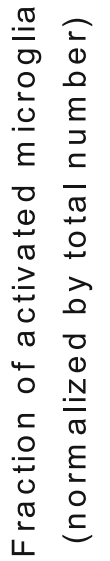
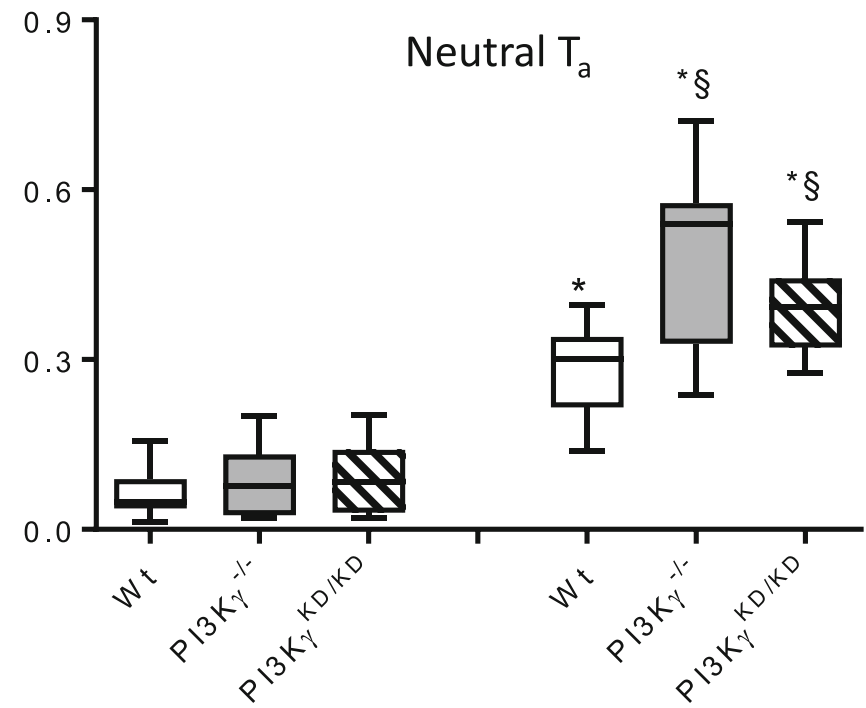

Fig. 4 Marked increase of microglial cell activation due to LPS-induced SIRS in brains of mice kept under neutral $T_{a}(\mathbf{a})$ and reduced $T_{a}$ (b). The effect is exacerbated by reduced $T_{a}$ in the wild-type mice, but not in the genetically modified animals. Values are presented as boxplots illustrating medians within boxes from first quartile to the third quartile and whiskers ranging from the 10th to the 90 th percentiles $(\mathbf{a}, \mathbf{b}: n=4-6$, at each group and experimental state. ${ }^{*}{ }^{\dagger} p<0.05$, asterisk indicates significant differences versus baseline within each group, section sign indicates significant differences versus wild-type mice kept under same $T_{a}$, dagger sign indicates significant differences versus mice kept under neutral $T_{a}$ at the same experimental state, two-way ANOVA, followed by Holm-Sidak test for post hoc multiple comparisons, each)

kept at reduced $\mathrm{T}_{\mathrm{a}}$. Taken together, the present data indicate an inhibitory role of reduced $\mathrm{T}_{\mathrm{a}}$ for the directional migration/chemotaxis of microglial cells from PI $3 \mathrm{~K} \gamma$ mutants.

Next, the role of modified $\mathrm{T}_{\mathrm{a}}$ ambient temperature for phagocytosis, another essential function of microglia, was analyzed. First, efficiency of phagocytosis was quantified by in vitro incubation of microglia with FITClabeled Zymosan particles and subsequent counting of incorporated particles inside the microglial cells. PI3K $\gamma$ deficiency caused a distinct decrease of phagocytosis of microglial cells under normal $\mathrm{T}_{\text {Inc }}$ (Fig. 7b, Suppl. Fig. 5). Under reduced $T_{\text {Inc }}$, quite similar effects have been ascertained. In vivo analysis of phagocytosis was performed by intracerebral administration of Zymosan particles. Under neutral $T_{a}$, counting the number of cells with phagocytosed particles revealed a reduction of microglial phagocytic activity in the brains derived from PI3K $\gamma^{-1-}$ mice. Reduced $\mathrm{T}_{\mathrm{a}}$ caused an additional distinct inhibition of phagocytic activity which was even more pronounced in PI $3 \gamma$-deficient mice.

\section{Discussion}

Our study identifies ambient temperature as a major impact factor for extent and clinical course of LPS-induced 


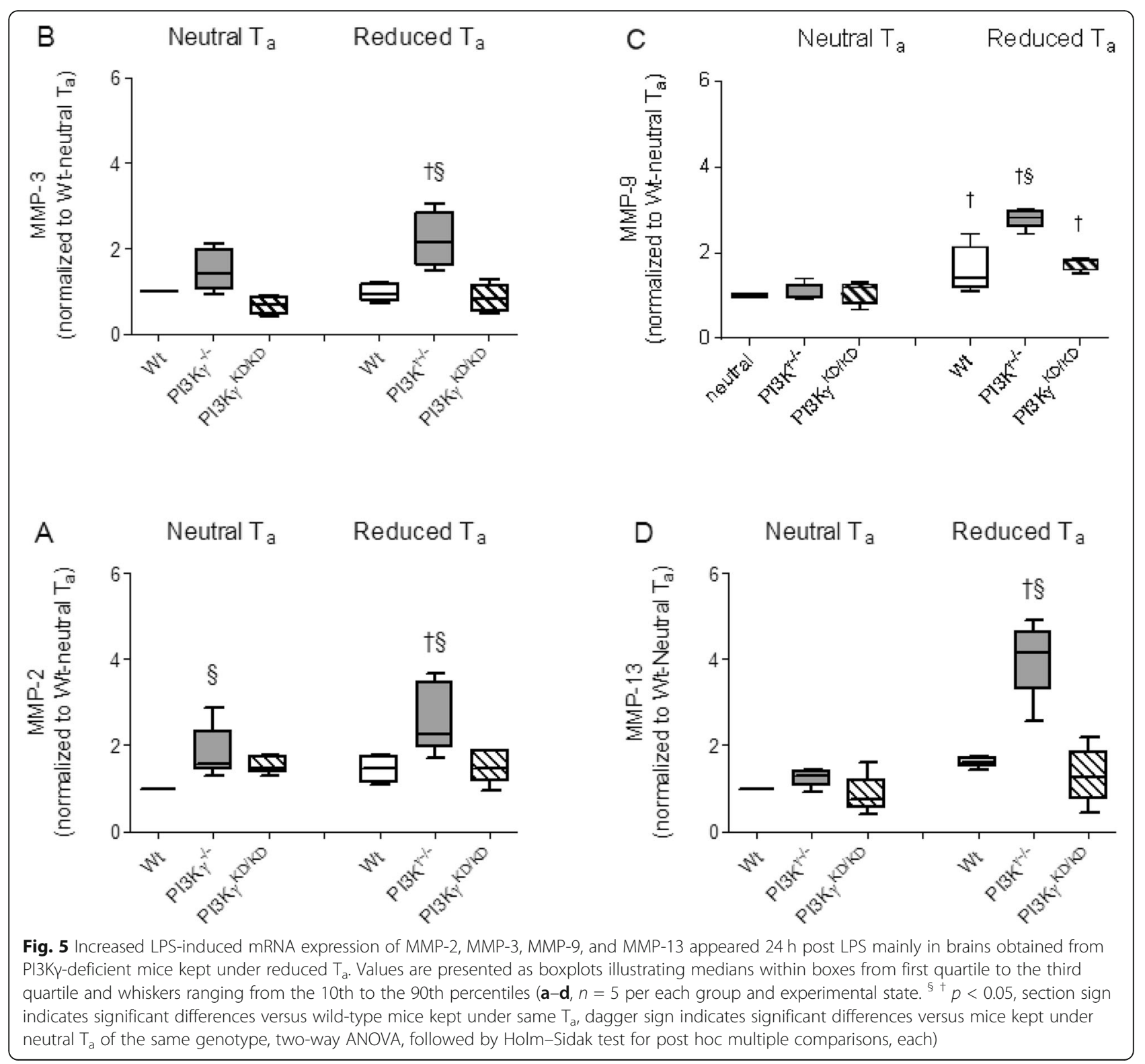

SIRS and concomitant blood-brain barrier breakdown as a key event in the development of SAE. We studied LPS-induced SIRS at a $\mathrm{T}_{\mathrm{a}}$ of $30^{\circ} \mathrm{C}$ (within thermoneutral zone for mice [46]) and at the upper edge of the recommended standard housing temperatures for laboratory mice, e.g., at $26^{\circ} \mathrm{C}[30,47]$. Importantly, recent guidelines for preclinical studies in sepsis research [48] and cerebrovascular research [49-51], with the emphasis to improve reproducibility and translational impact, neglected the impact of ambient temperature on pathogenesis of inflammatory diseases or did not consider that their recommended lower baseline limit for housing temperatures of small rodents causes chronic "cold" stress [52, 53]. Furthermore, ignoring the role of ambient temperature on basal physiological responsiveness in small animals frequently used in preclinical sepsis models leads to far-reaching repercussions of profound misinterpretation. Indeed, usage time course of body temperature for prognosis prediction under chronic cold stress for mice restricts statements of numerous pertinent reports [54-58] merely on the subgroup of septic patients endangered for cold challenge leading to accidental hypothermia [59]. The recent findings in mice showed that a reduced ambient temperature exacerbates SIRS-induced cardiac autonomic dysregulation and myocardial dysfunction [60]. This study in the heart supports the present results and conclusions on the brain response to cold stress.

We show for the first time that a reduction of $\mathrm{T}_{\mathrm{a}}$ of only $3-4^{\circ}$ below the lower critical $\mathrm{T}_{\mathrm{a}}$ for mice [61] 

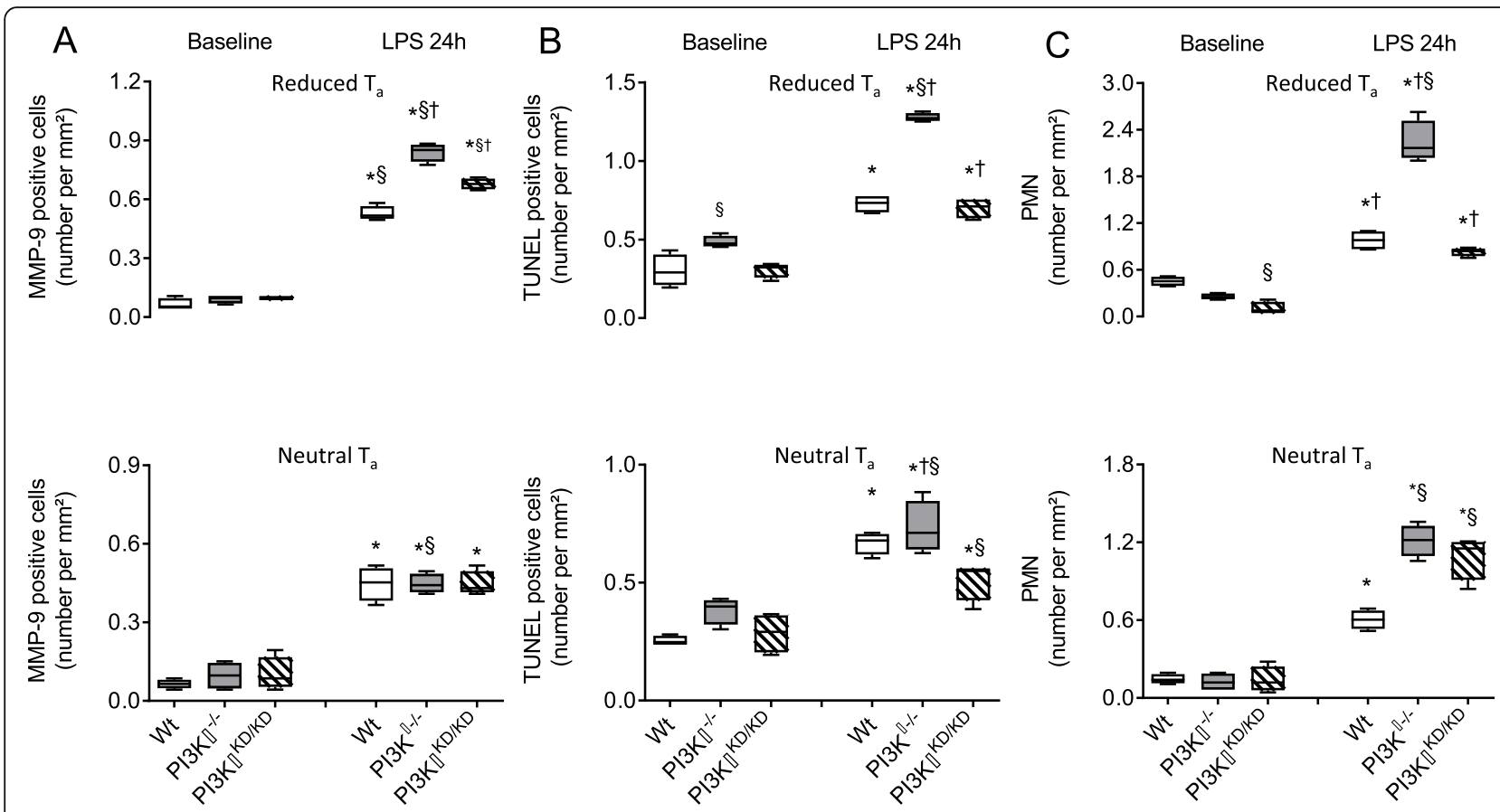

Fig. 6 Among the Iba1-positive cells, reduced $T_{a}$ (upper plot) $24 \mathrm{~h}$ after LPS administration resulted in an increased number of MMP-9 positive cells (a), number of TUNEL positive cells (b), and number of invading polymorphonuclear cells (PMN, c) appearing mainly in the brains obtained from PI3KY-deficient mice. Values are presented as boxplots illustrating medians within boxes from first quartile to the third quartile and whiskers ranging from the 10th to the 90th percentiles (lower panel: neutral $T_{a}$, upper panel: reduced $T_{a}, n=4$ per each group and experimental state. ${ }^{*} \$$ ${ }^{+} p<0.05$, asterisk indicates significant differences versus baseline of the same genotype and experimental state, section sign indicates significant differences versus wild type mice kept under same $T_{a}$, dagger sign indicates significant differences versus mice kept under neutral $T_{a}$ at the same experimental state, two-way ANOVA, followed by Holm-Sidak test for post hoc multiple comparisons, each)

increases the severity of BBB injury as a consequence of LPS-induced SIRS. This was clearly associated with a temporary disturbance of thermoregulation as a fundamental homeostatic function of all mammals because body core temperature was markedly reduced early after LPS-induced SIRS, and hypothermia persisted throughout the observed period (Fig. 2). Occurrence of hypothermia as a result of sepsis and overwhelming systemic inflammation characterizes a specific state of disturbed thermoregulation. Indeed, experimental and clinical studies clearly showed that severity of inflammation determines the magnitude of displacement from normothermia, e.g., mild to moderate SIRS induced by low and medium dosages of LPS provokes fever, whereas severe/life-threatening SIRS induces hypothermia [6264] as a result of decreased threshold of body temperature for activation of metabolic heat production [62, 65]. The mechanisms regulating hypothermia are not fully understood, but cytokines such as TNF- $\alpha$, interleukins (ILs), and interferon-gamma have been shown to induce or modulate hypothermia [66]. The herein presented data suggest that TNF- $\alpha$ may contribute to the hypothermic response because of a similar temporal profile. LPS-induced microglial activation may directly alter thermoregulation during systemic inflammation possibly by inducing cerebral endothelial activation [6769]. There is ample evidence that fever can be triggered by peripheral or intracerebrally administered (low-dose) LPS [70-72]. In contrast, hypothermic response to inflammation can be triggered only by (high-dose) LPS administered extra-cerebrally, i.e., systemically [73, 74]. Apparently, other factors play a relevant role in the extent of hypothermia early after LPS-induced SIRS. Clearly, $\mathrm{T}_{\mathrm{a}}$ determines depth of $\mathrm{T}_{c}$ reduction (Fig. 2). Therefore, hypothermic response appears to be a consequence of maladaptive thermoregulation leading to hypometabolism in order to avoid hypoxia [75].

PI3K $\gamma$-dependent differences in extent of sickness suggest that disturbance in behavioral thermoregulation may contribute to the manifestation of hypothermia. Small rodents such as mice need an increased metabolic rate and periodic motor activity for appropriate heat production to maintain homeothermy because of its unfavorable surface area versus mass ratio [61, 76]. Mice develop hypothermia when locomotor activity is diminished due to consequences of sickness induced by infection [77]. Our findings show that mice kept at reduced $\mathrm{T}_{\mathrm{a}}$ developed an exacerbated and prolonged hypothermia although they exhibited a markedly enhanced sympathetic tone. This might be related to a 


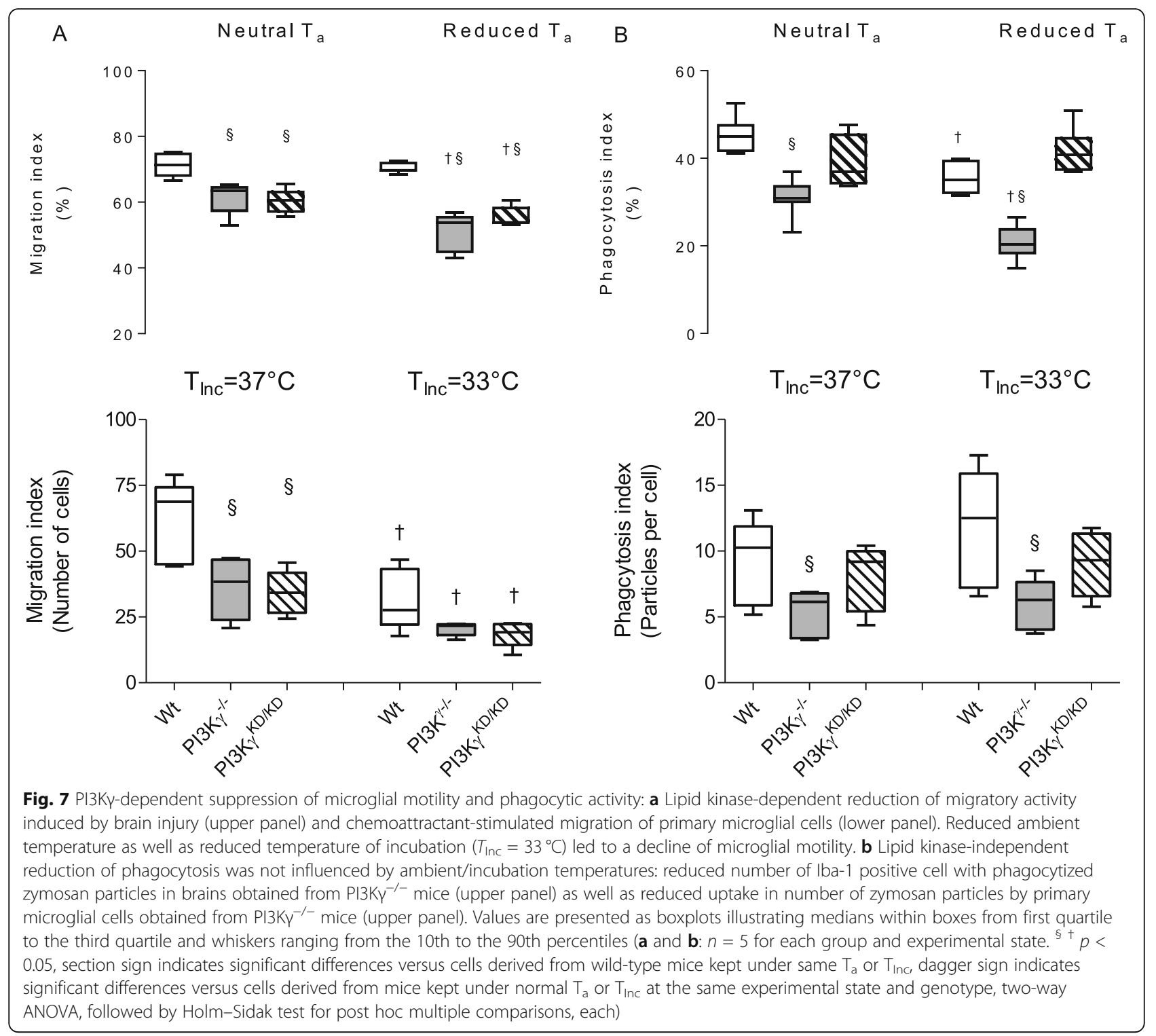

stronger impairment of thermoregulation with torporlike traits elicited by LPS-induced SIRS [78], in addition to LPS-induced inhibition of brown adipose tissue thermogenesis [79].

In a previous study, we have shown that the kinaseindependent control of cAMP phosphodiesterase activity by PI3K $\gamma$ acts as a crucial mediator of microglial cell activation, MMP expression, and subsequent BBB deterioration [5]. The data obtained in the current study suggest that an aggravated BBB breakdown observed in mice kept at reduced $\mathrm{T}_{\mathrm{a}}$ during LPS-induced SIRS results from an intensified LPS-induced proinflammatory microglial response. This response is accompanied by the pronounced upregulation of brain MMP expression and perivascular MMP-9 release leading to increased PMN invasion with altered microglial migration and phagocytosis. These processes appear to be widespread because we made similar findings in quite different brain regions. Enhanced plasma protein extravasation in brains obtained from PI3K $\gamma$-deficient mice kept under reduced $\mathrm{T}_{\mathrm{a}}$ suggests that the genotype-related differences in BBB breakdown appear to be related to microglial activation in response to systemic inflammation and concomitant brain tissue MMP upregulation. Compelling evidence suggests that early after SIRS manifestation, constitutive proteases are activated and begin the process of disassembling the extracellular matrix and opening the BBB $[80,81]$. Immunohistological evaluation revealed that there is an increased number of Iba- 1 positive cells which co-express MMP-9 in brains obtained from PI3K $\gamma$-deficient mice kept under reduced $\mathrm{T}_{a}$ (Fig. 6). Our previous results revealed that the enhanced MMP-9 
activity is of microglial origin and provoked by a deficient suppression of cAMP-dependent proinflammatory signaling in PI3K $\gamma$-deficient mice [5]. MMP-9 is known to act as an executing protease for degrading matrix substrates and interrupting cell-cell or cell-matrix homeostatic interactions, which may directly trigger anoikis-like neuronal cell death by interrupting cellmatrix survival signaling [82]. The current findings of aggravated SIRS-induced BBB impairment associated with reduced $T_{a}$ are clearly PI3K $\gamma$-dependent and induce an enhanced invasion of blood-born immune cells and an increased rate of apoptosis, especially in the hippocampus, when the suppressive effect of PI3K $\gamma$ on cAMP as a critical mediator of immune cell functions is absent $[5,32,83]$.

BBB impairment was revealed by EB extravasation into brain tissue indicative for plasma protein passage into brain tissue. EB remains the most commonly used marker of BBB integrity [84, 85]. Among the strengths of EB for studying BBB integrity are its immediate visibility and quantifiability allowing for group comparisons without usage of radioactive indicators $[5,36,86]$. However, there is now compelling evidence that results estimated by EB technique need to be viewed critically. Specifically, the general understanding is that EB binds tightly and nearly exclusively to plasma albumin. Therefore, EB extravasation into brain tissue is viewed as indication of an increased BBB permeability [87]. However, there is evidence that EB is additionally bound on some other plasma proteins, albeit with reduced physical binding $[88,89]$. Furthermore, with the conventionally used solution of $2 \% \mathrm{~EB}(4 \mathrm{ml} / \mathrm{kg})$ for in vivo administration, the plasma concentration of EB would not have exceeded the maximum binding capacity of albumin [84]. This is the technique we used in the present study. Nevertheless, because of the mode of binding, it has to be considered that a small fraction of free dye (0.11$0.31 \%)$ remained present and may be responsible for a certain level of background $[85,89,90]$. Other aspects of in vivo EB administration like toxicity or insufficient protein binding because of shortened contact time appear to be irrelevant for the results presented herein due to the experimental design chosen: Reported toxic effects were registered days or weeks after EB administration (overview is given in [84]); EB binding equilibration after bolus injection was reached within 5 min [91]. These temporal profiles do not apply in the present experimental conditions.

Causal relations responsible for associated exacerbated brain injury cannot be drawn conclusively. Indeed, this study is limited in detailed mechanistic explanation of microglial role in BBB alterations. Future work needs to include approaches for fine-grained analysis of microglia spatial and temporal heterogeneity on the single-cell level [6]. Nevertheless, a reduced ability of directed motility and diminished phagocytic activity in the brains obtained from PI3K $\gamma$-deficient mice kept under reduced $\mathrm{T}_{\mathrm{a}}$ suggest that these altered cell functions contribute to the phenotype of enhanced structural and functional cerebral disturbance leading to aggravated SAE symptoms. We identified the lipid kinase activity of PI3K $\gamma$ as an essential mediator of microglial migration [92]. Furthermore, diminished microglial phagocytic activity appears to contribute to the enhanced proinflammatory brain response to LPS-induced SIRS in PI3K $\gamma$-deficient mice kept under reduced $T_{a}$ because microglial phagocytosis represents a key factor for limiting excessive proinflammatory activation by clearance of dying cells and debris in injured brain tissue [14, 93, 94].

The agreement between our findings obtained from in vivo experiments performed in mice and cell culture assays regarding cell motility and phagocytosis activity supports our inference on the impact of the interactions of microglial cells, the genotype, and environmental temperature on systemic inflammation and severity of brain injury. It has been shown that many features of microglial activation can be reproduced in primary cell culture [95]. Nevertheless, neonatal microglial isolation for cell culturing is a challenge because several necessities alter the basic environmental conditions with sustained functional consequences: (i) separation of microglia from neighboring cells and the tissue matrix requires extensive tissue damage resembling microglial features typical for injured tissue [96, 97]; (ii) high purity of microglial cells in cell culture (>95\%) is one of the intended objectives for mechanistic approaches and one of the most popular strengths. However, this also abolishes the interaction with surrounding neurons, other glia cells, and extracellular matrix, with far-reaching consequences on microglial response patterns [14, 98]; (iii) in vitro survival and increase of yielded microglia necessitate serum supplement, which consequently induces microglial activation [37, 99].

Therefore, interpretation of results obtained from microglial cell culture experiments requires caution. Comparative discussion, as we did here, with corresponding experimental approaches in similar animal models allows critical assessment of the experimental data and reduces the risk of misinterpretation.

In addition, it is necessary to take into account the typically lower cell yield during neonatal microglial isolation. This creates challenges in getting sufficient cell numbers to perform primary microglial cell culture experiments. Therefore, (i) a rather high number of animals must be sacrificed for each experiment. Keeping in mind the necessity for enforced application of high animal welfare standards, an ethical evaluation and consideration of the scientific significance, e.g., a scientific 
validation for harm-benefit analysis for each and every experiment has to be considered [100, 101]; (ii) in order to warrant a sufficient cell number and appropriate purity of neonatal microglia for in vitro approaches, different methods have been described and comprehensively reviewed $[99,102,103]$. The herein used method is based on the most frequently used differential adherence method. Mixed glial cultures are obtained and allowed to grow to confluency. The microglial cells are then separated from the adherent astrocyte layer by gently shaking [104]. The resulting microglial cell population appears highly pure and exhibits a largely uniform phenotype compared with the diversity of phenotypes observed in vivo [105]. Therefore, such in vitro approaches have allowed for an intimate exploration of key activation and signaling pathways [106].

Some additional methodological implications have to be considered. Categorization and classification of microglia and phagocytic indexing by Ibal staining appear to be appropriate methodological approaches [107] used in numerous studies (see below). Specifically, Iba1 is known to be constitutively expressed by microglia within the brain parenchyma. Iba1 is only moderately expressed by quiescent ramified microglia and not at all by astrocytes, oligodendrocytes, or neurons [108]. Iba1 is a protein that acts to modulate membrane-ruffling changes during microglial activation [108]. Therefore, Ibal appears to be a suitable indicator for microglial indexing and has been extensively used to identify, count, or gage activation of microglia within the CNS [109-113]. Furthermore, while the morphometric analysis of microglia for indexing the microglial activation status was the first approach characterizing different microglial response states [114-116], it remains also an appropriate measure for microglial activation, in particular if the expression level of several molecular biomarkers, such as Iba1, is mostly increasing with microglial activation [14]. In addition, brain histological analysis revealed a clear regional pattern, which enhanced the significance of our findings on the impact of ambient temperature on inflammation-induced encephalopathy in endotoxemic mice. In addition, we used methods for analyses of two key microglial cell functions, i.e., migration and phagocytosis, which are both well-documented [41, 117-121] and wellestablished in our lab, having been used successfully for years [40, 92, 122].

We consider the following aspects as strengths of the experimental design used herein: (i) two experimental groups of mice kept at neutral $\left(30 \pm 0.5^{\circ} \mathrm{C}\right)$ or moderately lowered $\left(26 \pm 0.5^{\circ} \mathrm{C}\right) \mathrm{T}_{\mathrm{a}}$. (ii) Three different genotypes were used which together are suited to clarify mechanistically the role of the signaling protein $\mathrm{PI} 3 \mathrm{~K} \gamma$ [5, 8, 92, 94, 122-124]. Therefore, the two different
PI3K $\gamma$ 's main functions were studied: PI3K $\gamma$ lipid kinase activity producing of phosphatidylinositol 3,4,5-trisphosphate and protein kinase Akt/PKB activation, and/or kinase-independent control of cAMP phosphodiesterase activity. (iii) Using the in vitro approach with pure microglia cell cultures derived from the three mice genotypes allowed to clarify the role of microglia and PI $3 \mathrm{~K} \gamma$ more mechanistically.

Taken together, we put forward that the multifaceted methodological approach and the experimental design deployed in this study conclusively validate our main hypothesis that thermoregulatory response to hypothermia (reduced $\mathrm{T}_{\mathrm{a}}$ ) aggravates $\mathrm{SAE}$ in $\mathrm{PI} 3 \mathrm{~K} \gamma$-dependent manner.

\section{Conclusions}

Our findings underline the importance of ambient temperature as a frequently neglected yet crucial environmental condition in translational inflammatory/infectious diseases research. The major significance of our findings is that a modest variation of an easily controllable parameter, i.e., the ambient temperature, led to a serious impact on the course of SAE. Furthermore, our data reveal the signaling protein $\mathrm{PI} 3 \mathrm{~K} \gamma$ as a critical mediator of key microglial cell functions involved in LPS-induced BBB injury and accompanying neuroinflammation. PI3KY serves a protective role in that it suppresses MMP release, maintains microglial motility, and reinforces phagocytosis leading to improved brain tissue integrity.

Thus, this study substantiates the importance of controlling $\mathrm{T}_{\mathrm{a}}$ tightly to prevent serious bias in results from preclinical animal research on inflammation/infection. Accounting for $\mathrm{T}_{\mathrm{a}}$ will improve the predictive power and value of the neuroinflammatory research and help overcome the "replication crisis" [125].

\section{Supplementary information}

Supplementary information accompanies this paper at https://doi.org/10. 1186/s12974-020-01954-7.

\section{Additional file 1.}

\section{Abbreviations}

5'-AMP: Adenosine monophosphate; Akt: Protein kinase B; BBB: Blood-brain barrier: C5a: Complement component 5a; cAMP: Cyclic adenosine

monophosphate; CDNA: Complementary DNA; CNS: Central nervous system; DAPI: 4',6-diamidino-2-phenylindole; DMEM: Dulbecco/Nogt modified Eagle's minimal essential medium; EB: Evans blue; ECG: Electrocardiography; EDTA: Ethylenediaminetetraacetic acid; FCS: Fetal calf serum;

FITC: Fluoresceinisothiocyanate; GAPDH: Glyceraldehyde 3-phosphate de-

hydrogenase; HR: Instantaneous heart rate; IL-6: Interleukin 6; IL-

10: Interleukin 10; LPS: Lipopolysaccharides; MCP-1: Monocyte

chemoattractant protein 1; MMPs: Matrix metalloproteinases; mRNA: Messenger RNA; PBS: Phosphate-buffered saline;

PFA: Paraformaldehyde; PI3KY: Phosphoinositide 3-kinase ; $\mathrm{PISKY}^{-1-}$ : PI3KY knockout; PI3K $\mathrm{K}^{\mathrm{KD} / \mathrm{KD}}$ : Mutation in the PI3KY gene causing loss of lipid kinase activity; PKA: Protein kinase A; PMN: Polymorphonuclear neutrophil; 
qPCR: Quantitative PCR; SAE: Sepsis-associated encephalopathy; SIRS: Systemic inflammatory response syndrome; Ta: Ambient temperature; TC: Core body temperature; TInc: Incubation temperature; TNF-a: Tumor necrosis factor alpha

\section{Acknowledgements}

The authors acknowledge Mrs. R.-M. Zimmer for skillful technical assistance.

\section{Authors' contributions}

RB and RW conceived and designed the study. G-PL performed in vitro experiments and analyzed most of the experiments. RB and BN-D supervised the experimental program and performed animal experiments. RB prepared the manuscript. $\mathrm{TL}, \mathrm{MB}$, and $\mathrm{YH}$ performed some of the immunohistochemistry and data analysis. MGF and RW edited the manuscript. All authors approved the final version of the manuscript.

\section{Funding}

The study was supported by the Deutsche Forschungsgemeinschaft [R.B.] [DFG, Grant RTG 1715]. B.N.-D. received funding from the European Union Seventh Framework Programme (FP7-PEOPLE-2013-COFUND) under grant agreement no 609020 - Scientia Fellows, G.P.L. received a scholarship from the China Scholarship Council. Open Access funding enabled and organized by Projekt DEAL.

\section{Availability of data and materials}

The datasets used and/or analyzed during the current study are available from the corresponding author upon reasonable request.

\section{Ethics approval and consent to participate}

This study involves animal experiment and includes a statement on ethics approval.

\section{Consent for publication}

Not applicable

\section{Competing interests}

The authors declare that they have no competing interests.

\section{Author details}

${ }^{1}$ Institute of Molecular Cell Biology, Jena University Hospital, Friedrich Schiller University, Hans-Knöll-Straße 2, D-07745 Jena, Germany. ${ }^{2}$ Joint International Research Laboratory of Ethnomedicine and Key Laboratory of Basic Pharmacology of Ministry of Education, Zunyi Medical University, Zunyi 563006, China. ${ }^{3}$ Department of Pharmacology, University of Oslo and Oslo University Hospital, Oslo, Norway. ${ }^{4}$ Department of Neonatology, University Children's Hospital, Heidelberg, Germany. ${ }^{5}$ Department of Pathology, Helios-Klinikum Erfurt, Erfurt, Germany. ${ }^{6}$ Institute of Biochemistry I, Faculty of Medicine, Goethe-University Frankfurt, 60590 Frankfurt, Germany.

${ }^{7}$ Department of Anesthesiology and Intensive Care Medicine, Jena University Hospital, Friedrich Schiller University, Jena, Germany. ${ }^{8}$ University of Washington School of Medicine, Seattle, WA, USA.

Received: 4 April 2020 Accepted: 16 September 2020

Published online: 07 October 2020

\section{References}

1. Tauber SC, Eiffert H, Bruck W, Nau R. Septic encephalopathy and septic encephalitis. Expert Rev Anti Infect Ther. 2017;15:121-32.

2. Gofton TE, Young GB. Sepsis-associated encephalopathy. Nat Rev Neurol. 2012;8:557-66.

3. Annane D, Sharshar T. Cognitive decline after sepsis. Lancet Respir Med. 2015:3:61-9.

4. Kuperberg SJ, Wadgaonkar R. Sepsis-associated encephalopathy: the bloodbrain barrier and the sphingolipid rheostat. Front Immunol. 2017;8:597.

5. Frister A, Schmidt C, Schneble N, Brodhun M, Gonnert FA, Bauer M, Hirsch E, Muller JP, Wetzker R, Bauer R. Phosphoinositide 3-kinase gamma affects LPSinduced disturbance of blood-brain barrier via lipid kinase-independent control of cAMP in microglial cells. Neuromolecular Med. 2014;16:704-13.

6. Prinz $M$, Jung $S$, Priller J. Microglia biology: one century of evolving concepts. Cell. 2019;179:292-311.
7. Wendeln AC, Degenhardt K, Kaurani L, Gertig M, Ulas T, Jain G, Wagner J, Hasler LM, Wild K, Skodras A, et al. Innate immune memory in the brain shapes neurological disease hallmarks. Nature. 2018;556:332-8.

8. Lajqi T, Lang GP, Haas F, Williams DL, Hudalla H, Bauer M, Groth M, Wetzker $R$, Bauer R. Memory-like inflammatory responses of microglia to rising doses of LPS: key role of PI3Kgamma. Front Immunol. 2019;10:2492.

9. Low D, Ginhoux F. Recent advances in the understanding of microglial development and homeostasis. Cell Immunol. 2018;330:68-78.

10. Tay TL, Savage JC, Hui CW, Bisht K, Tremblay ME. Microglia across the lifespan: from origin to function in brain development, plasticity and cognition. J Physiol. 2017;595:1929-45.

11. Nimmerjahn A, Kirchhoff F, Helmchen F. Resting microglial cells are highly dynamic surveillants of brain parenchyma in vivo. Science. 2005;308:1314-8.

12. Hanisch UK, Kettenmann H. Microglia: active sensor and versatile effector cells in the normal and pathologic brain. Nat Neurosci. 2007;10:1387-94.

13. Salter MW, Stevens B. Microglia emerge as central players in brain disease. Nat Med. 2017:23:1018-27.

14. Kettenmann H, Hanisch UK, Noda M, Verkhratsky A. Physiology of microglia. Physiol Rev. 2011;91:461-553.

15. Ransohoff RM, Cardona AE. The myeloid cells of the central nervous system parenchyma. Nature. 2010;468:253-62.

16. Davalos D, Grutzendler J, Yang G, Kim JV, Zuo Y, Jung S, Littman DR, Dustin ML, Gan WB. ATP mediates rapid microglial response to local brain injury in vivo. Nat Neurosci. 2005:8:752-8.

17. Streit WJ, Kincaid-Colton CA. The brain's immune system. Sci Am. 1995;273: 54-5 58-61.

18. Wolf SA, Boddeke HW, Kettenmann H. Microglia in physiology and disease. Annu Rev Physiol. 2017;79:619-43.

19. Ransohoff RM. A polarizing question: do M1 and M2 microglia exist? Nat Neurosci. 2016:19:987-91.

20. Gertig U, Hanisch UK. Microglial diversity by responses and responders. Front Cell Neurosci. 2014:8:101.

21. Eggen BJ, Raj D, Hanisch UK, Boddeke HW. Microglial phenotype and adaptation. J Neuroimmune Pharmacol. 2013:8:807-23.

22. Nakamura K. Central circuitries for body temperature regulation and fever Am J Physiol Regul Integr Comp Physiol. 2011:301:R1207-28.

23. Nakamura Y, Nakamura K. Central regulation of brown adipose tissue thermogenesis and energy homeostasis dependent on food availability. Pflugers Arch. 2018;470:823-37.

24. Clemmer TP, Fisher CJ Jr, Bone RC, Slotman GJ, Metz CA, Thomas FO. Hypothermia in the sepsis syndrome and clinical outcome. The Methylprednisolone Severe Sepsis Study Group. Crit Care Med. 1992;20: 1395-401.

25. Young PJ, Saxena M, Beasley R, Bellomo R, Bailey M, Pilcher D, Finfer S, Harrison D, Myburgh J, Rowan K. Early peak temperature and mortality in critically ill patients with or without infection. Intensive Care Med. 2012:38:437-44.

26. Schortgen F. Fever in sepsis. Minerva Anestesiol. 2012;78:1254-64.

27. Cumming J, Purdue GF, Hunt JL, O'Keefe GE. Objective estimates of the incidence and consequences of multiple organ dysfunction and sepsis after burn trauma. J Trauma. 2001:50:510-5.

28. Soreide K. Clinical and translational aspects of hypothermia in major trauma patients: from pathophysiology to prevention, prognosis and potential preservation. Injury. 2014;45:647-54.

29. Overton JM. Phenotyping small animals as models for the human metabolic syndrome: thermoneutrality matters. Int J Obes (Lond). 2010; 34(Suppl 2):S53-8.

30. EP. C: Directive 2010/63/EU of the European Parliament and of the council on the protection of animals used for scientific purposes. Off J Euro Union L 2010, 276:33-79.

31. Hirsch E, Katanaev VL, Garlanda C, Azzolino O, Pirola L, Silengo L, Sozzani S, Mantovani A, Altruda F, Wymann MP. Central role for G protein-coupled phosphoinositide 3-kinase gamma in inflammation. Science. 2000;287:1049-53.

32. Patrucco E, Notte A, Barberis L, Selvetella G, Maffei A, Brancaccio M, Marengo S, Russo G, Azzolino O, Rybalkin SD, et al. PI3Kgamma modulates the cardiac response to chronic pressure overload by distinct kinasedependent and -independent effects. Cell. 2004;118:375-87.

33. Obernier JA, Baldwin RL. Establishing an appropriate period of acclimatization following transportation of laboratory animals. ILAR J. 2006; 47:364-9. 
34. Gordon CJ, Becker P, Ali JS. Behavioral thermoregulatory responses of single- and group-housed mice. Physiol Behav. 1998;65:255-62.

35. Gonnert FA, Recknagel P, Seidel M, Jbeily N, Dahlke K, Bockmeyer CL, Winning J, Losche W, Claus RA, Bauer M. Characteristics of clinical sepsis reflected in a reliable and reproducible rodent sepsis model. J Surg Res. 2011;170:e123-34

36. Comim CM, Vilela MC, Constantino LS, Petronilho F, Vuolo F, LacerdaQueiroz N, Rodrigues DH, da Rocha JL, Teixeira AL, Quevedo J, Dal-Pizzol F. Traffic of leukocytes and cytokine up-regulation in the central nervous system in sepsis. Intensive Care Med. 2011;37:711-8.

37. Giulian D, Baker TJ. Characterization of ameboid microglia isolated from developing mammalian brain. J Neurosci. 1986;6:2163-78.

38. Lian $\mathrm{H}$, Roy $\mathrm{E}$, Zheng $\mathrm{H}$. Protocol for primary microglial culture preparation. Bio Protoc. 2016;6.

39. Livak KJ, Schmittgen TD. Analysis of relative gene expression data using real-time quantitative PCR and the 2(-Delta Delta C(T)) method. Methods. 2001:25:402-8.

40. Schneble N, Muller J, Kliche S, Bauer R, Wetzker R, Bohmer FD, Wang ZQ, Muller JP. The protein-tyrosine phosphatase DEP-1 promotes migration and phagocytic activity of microglial cells in part through negative regulation of fyn tyrosine kinase. Glia. 2017;65:416-28.

41. Seo JW, Kim JH, Kim JH, Seo M, Han HS, Park J, Suk K. Time-dependent effects of hypothermia on microglial activation and migration. J Neuroinflammation. 2012;9:164

42. Sun SF, Pan QZ, Hui X, Zhang BL, Wu HM, Li H, Xu W, Zhang Q, Li JY, Deng $\mathrm{XM}$, et al. Stronger in vitro phagocytosis by monocytes-macrophages is indicative of greater pathogen clearance and antibody levels in vivo. Poult Sci. 2008:87:1725-33.

43. Paxinos G, Franklin KBJ. The mouse brain in stereotaxic coordinates. San Diego: Academic Press; 2001.

44. Brodhun M, Fritz H, Walter B, Antonow-Schlorke I, Reinhart K, Zwiener U, Bauer R, Patt S. Immunomorphological sequelae of severe brain injury induced by fluid-percussion in juvenile pigs--effects of mild hypothermia. Acta Neuropathol. 2001;101:424-34

45. Zhang F, Vadakkan Kl, Kim SS, Wu LJ, Shang Y, Zhuo M. Selective activation of microglia in spinal cord but not higher cortical regions following nerve injury in adult mouse. Mol Pain. 2008;4:15.

46. Gordon CJ. Toxic-induced hypothermia and hypometabolism: do they increase uncertainty in the extrapolation of toxicological data from experimental animals to humans? Neurosci Biobehav Rev. 1991;15:95-8.

47. NRC: Guide for the care and use of laboratory animals. Council of the National Academy of Science. Volume 8th ed. Nat. Res. Washington,DC: The National Academy Press; 2011.

48. Zingarelli B, Coopersmith CM, Drechsler S, Efron P, Marshall JC, Moldawer L, Wiersinga WJ, Xiao X, Osuchowski MF, Thiemermann C. Part I: minimum quality threshold in preclinical sepsis studies (MQTiPSS) for study design and humane modeling endpoints. Shock. 2019:51:10-22.

49. Percie du Sert N, Alfieri A, Allan SM, Carswell HV, Deuchar GA, Farr TD, Flecknell P, Gallagher L, Gibson CL, Haley MJ, et al. The IMPROVE guidelines (ischaemia models: procedural refinements of in vivo experiments). J Cereb Blood Flow Metab. 2017:37:3488-517.

50. Howells DW, Sena ES, Macleod MR. Bringing rigour to translational medicine. Nat Rev Neurol. 2014;10:37-43.

51. Vahidy F, Schabitz WR, Fisher M, Aronowski J. Reporting standards for preclinical studies of stroke therapy. Stroke. 2016;47:2435-8.

52. Hankenson FC, Marx JO, Gordon CJ, David JM. Effects of rodent thermoregulation on animal models in the research environment. Comp Med. 2018;68:425-38.

53. Hylander BL, Gordon CJ, Repasky EA. Manipulation of ambient housing temperature to study the impact of chronic stress on immunity and cancer in mice. J Immunol. 2019;202:631-6.

54. Drechsler S, Weixelbaumer KM, Weidinger A, Raeven P, Khadem A, Redl H, van Griensven M, Bahrami S, Remick D, Kozlov A, Osuchowski MF. Why do they die? Comparison of selected aspects of organ injury and dysfunction in mice surviving and dying in acute abdominal sepsis. Intensive Care Med Exp. 2015;3:48

55. Laitano O, Van Steenbergen D, Mattingly AJ, Garcia CK, Robinson GP, Murray KO, Clanton TL, Nunamaker EA. Xiphoid surface temperature predicts mortality in a murine model of septic shock. Shock. 2018;50:226-32.

56. Miao $P$, Kong $Y, M a Y$, Zeng $H, Y u Z$. Hypothermia predicts the prognosis in colon ascendens stent peritonitis mice. J Surg Res. 2013;181:129-35.
57. Rothe P, Sommerfeld O, Queissner CH, Otto GP, Sossdorf M, Richter A, Claus RA. Continuous non-invasive infrared monitoring in animal research during infectious diseases. Infection. 2015;43:S67-8.

58. Trammell RA, Toth LA. Markers for predicting death as an outcome for mice used in infectious disease research. Comp Med. 2011;61:492-8.

59. Mallet ML. Pathophysiology of accidental hypothermia. QJM. 2002;95:775-85.

60. Ndongson-Dongmo B, Lang GP, Mece O, Hechaichi N, Lajai T, Hoyer D, Brodhun M, Heller R, Wetzker R, Franz M, et al. Reduced ambient temperature exacerbates SIRS-induced cardiac autonomic dysregulation and myocardial dysfunction in mice. Basic Res Cardiol. 2019;114:26.

61. Gordon CJ. The mouse thermoregulatory system: its impact on translating biomedical data to humans. Physiol Behav. 2017;179:55-66.

62. Romanovsky AA, Shido O, Sakurada S, Sugimoto N, Nagasaka T. Endotoxin shock: thermoregulatory mechanisms. Am J Physiol. 1996;270:R693-703.

63. Rudaya AY, Steiner AA, Robbins JR, Dragic AS, Romanovsky AA. Thermoregulatory responses to lipopolysaccharide in the mouse: dependence on the dose and ambient temperature. Am J Physiol Regul Integr Comp Physiol. 2005;289:R1244-52.

64. Kushimoto S, Yamanouchi S, Endo T, Sato T, Nomura R, Fujita M, Kudo D, Omura T, Miyagawa N, Sato T. Body temperature abnormalities in non-neurological critically ill patients: a review of the literature. J Intensive Care. 2014:2:14.

65. Romanovsky AA, Shido O, Sakurada S, Sugimoto N, Nagasaka T: Endotoxin shock-associated hypothermia. How and why does it occur? Ann N Y Acad Sci 1997, 813:733-737.

66. Leon LR. Hypothermia in systemic inflammation: role of cytokines. Front Biosci. 2004;9:1877-88

67. Breder CD, Saper CB. Expression of inducible cyclooxygenase mRNA in the mouse brain after systemic administration of bacterial lipopolysaccharide. Brain Res. 1996;713:64-9.

68. Elmquist JK, Breder CD, Sherin JE, Scammell TE, Hickey WF, Dewitt D, Saper CB. Intravenous lipopolysaccharide induces cyclooxygenase 2-like immunoreactivity in rat brain perivascular microglia and meningeal macrophages. J Comp Neurol. 1997;381:119-29.

69. Zhou H, Lapointe BM, Clark SR, Zbytnuik L, Kubes P. A requirement for microglial TLR4 in leukocyte recruitment into brain in response to lipopolysaccharide. J Immunol. 2006;177:8103-10.

70. Yamagata K, Matsumura K, Inoue W, Shiraki T, Suzuki K, Yasuda S, Sugiura H, Cao C, Watanabe Y, Kobayashi S. Coexpression of microsomal-type prostaglandin E synthase with cyclooxygenase-2 in brain endothelial cells of rats during endotoxin-induced fever. J Neurosci. 2001;21:2669-77.

71. Matsumura K, Cao C, Ozaki M, Morii H, Nakadate K, Watanabe Y. Brain endothelial cells express cyclooxygenase-2 during lipopolysaccharideinduced fever: light and electron microscopic immunocytochemical studies. J Neurosci. 1998;18:6279-89.

72. Cao C, Matsumura K, Yamagata K, Watanabe Y. Involvement of cyclooxygenase-2 in LPS-induced fever and regulation of its mRNA by LPS in the rat brain. Am J Physiol. 1997:272:R1712-25.

73. Al-Saffar H, Lewis K, Liu E, Schober A, Corrigan JJ, Shibata K, Steiner AA. Lipopolysaccharide-induced hypothermia and hypotension are associated with inflammatory signaling that is triggered outside the brain. Brain Behav Immun. 2013:28:188-95.

74. Garami A, Steiner AA, Romanovsky AA. Fever and hypothermia in systemic inflammation. Handb Clin Neurol. 2018:157:565-97.

75. Corrigan JJ, Fonseca MT, Flatow EA, Lewis K, Steiner AA. Hypometabolism and hypothermia in the rat model of endotoxic shock: independence of circulatory hypoxia. J Physiol. 2014;592:3901-16.

76. Cannon B, Nedergaard J. Nonshivering thermogenesis and its adequate measurement in metabolic studies. J Exp Biol. 2011;214:242-53.

77. Jhaveri KA, Trammell RA, Toth LA. Effect of environmental temperature on sleep, locomotor activity, core body temperature and immune responses of C57BL/6 J mice. Brain Behav Immun. 2007;21:975-87.

78. Szentirmai E, Krueger JM. Sickness behaviour after lipopolysaccharide treatment in ghrelin deficient mice. Brain Behav Immun. 2014;36:200-6.

79. Okla M, Wang W, Kang I, Pashaj A, Carr T, Chung S. Activation of Toll-like receptor 4 (TLR4) attenuates adaptive thermogenesis via endoplasmic reticulum stress. J Biol Chem. 2015;290:26476-90.

80. Rosenberg GA. Neurological diseases in relation to the blood-brain barrier. J Cereb Blood Flow Metab. 2012:32:1139-51.

81. Candelario-Jalil E, Yang Y, Rosenberg GA. Diverse roles of matrix metalloproteinases and tissue inhibitors of metalloproteinases in neuroinflammation and cerebral ischemia. Neuroscience. 2009;158:983-94. 
82. Gu Z, Kaul M, Yan B, Kridel SJ, Cui J, Strongin A, Smith JW, Liddington RC, Lipton SA. S-nitrosylation of matrix metalloproteinases: signaling pathway to neuronal cell death. Science. 2002;297:1186-90.

83. Perino A, Beretta M, Kilic A, Ghigo A, Carnevale D, Repetto IE, Braccini L, Longo D, Liebig-Gonglach M, Zaglia T, et al: Combined inhibition of PI3Kbeta and PI3Kgamma reduces fat mass by enhancing alpha-MSHdependent sympathetic drive. Sci Signal 2014, 7:ra110.

84. Saunders NR, Dziegielewska KM, Mollgard K, Habgood MD, Wakefield MJ, Lindsay H, Stratzielle N, Ghersi-Egea JF, Liddelow SA. Influx mechanisms in the embryonic and adult rat choroid plexus: a transcriptome study. Front Neurosci. 2015;9:123.

85. Yao L, Xue X, Yu P, Ni Y, Chen F. Evans blue dye: a revisit of its applications in biomedicine. Contrast Media Mol Imaging. 2018;2018:7628037.

86. Singhal AB, Wang $X$, Sumii T, Mori T, Lo EH. Effects of normobaric hyperoxia in a rat model of focal cerebral ischemia-reperfusion. J Cereb Blood Flow Metab. 2002;22:861-8.

87. Wolman M, Klatzo I, Chui E, Wilmes F, Nishimoto K, Fujiwara K, Spatz M. Evaluation of the dye-protein tracers in pathophysiology of the blood-brain barrier. Acta Neuropathol. 1981:54:55-61.

88. Le VH, Fishman WH. Combination of Evans blue with plasma protein; its significance in capillary permeability studies, blood dye disappearance curves, and its use as a protein tag. Am J Physiol. 1947;151:26-33.

89. Emmett $M$, Cerniglia CE, Crowle AJ. Differential serum protein binding of benzidine- and benzidine-congener based dyes and their derivatives. Arch Toxicol. 1985;57:130-5

90. Allen TH, Orahovats PD. Combination of toluidine dye isomers with plasma albumin. Am J Physiol. 1950;161:473-82.

91. Yen LF, Wei VC, Kuo EY, Lai TW. Distinct patterns of cerebral extravasation by Evans blue and sodium fluorescein in rats. PLoS One. 2013;8:e68595.

92. Schneble N, Schmidt C, Bauer R, Muller JP, Monajembashi S, Wetzker R. Phosphoinositide 3-kinase gamma ties chemoattractant- and adrenergic control of microglial motility. Mol Cell Neurosci. 2017;78:1-8.

93. Neumann H, Kotter MR, Franklin RJ. Debris clearance by microglia: an essential link between degeneration and regeneration. Brain. 2009;132: 288-95.

94. Schmidt C, Frahm C, Schneble N, Muller JP, Brodhun M, Franco I, Witte OW, Hirsch E, Wetzker R, Bauer R. Phosphoinositide 3-kinase gamma restrains neurotoxic effects of microglia after focal brain ischemia. Mol Neurobiol. 2016:53:5468-79.

95. Bennett ML, Bennett FC, Liddelow SA, Ajami B, Zamanian JL, Fernhoff NB, Mulinyawe SB, Bohlen CJ, Adil A, Tucker A, et al. New tools for studying microglia in the mouse and human CNS. Proc Natl Acad Sci U S A. 2016; 113:E1738-46.

96. Bohlen CJ, Bennett FC, Tucker AF, Collins HY, Mulinyawe SB, Barres BA. Diverse requirements for microglial survival, specification, and function revealed by defined-medium cultures. Neuron. 2017;94:759-73 e758

97. Stansley B, Post J, Hensley K. A comparative review of cell culture systems for the study of microglial biology in Alzheimer's disease. J Neuroinflammation. 2012;9:115

98. Ransohoff RM, Perry VH. Microglial physiology: unique stimuli, specialized responses. Annu Rev Immunol. 2009;27:119-45.

99. Witting A, Moller T. Microglia cell culture: a primer for the novice. Methods Mol Biol. 2011:758:49-66.

100. Russell WMS, Burch RL. The principles of humane experimental technique. In. London, UK: Methuen; 1959.

101. Wurbel H. More than 3Rs: the importance of scientific validity for harmbenefit analysis of animal research. Lab Anim (NY). 2017;46:164-6.

102. Roque PJ, Costa LG: Co-culture of neurons and microglia. Curr Protoc Toxicol 2017, 74:11 24 11-11 2417

103. Ni M, Aschner M: Neonatal rat primary microglia: isolation, culturing, and selected applications. Curr Protoc Toxicol 2010, Chapter 12:Unit 1217.

104. Floden AM, Combs CK. Microglia repetitively isolated from in vitro mixed glial cultures retain their initial phenotype. J Neurosci Methods. 2007;164: 218-24.

105. Carson MJ, Crane J, Xie AX. Modeling CNS microglia: the quest to identify predictive models. Drug Discov Today Dis Models. 2008;5:19-25.

106. Baburamani AA, Supramaniam VG, Hagberg H, Mallard C. Microglia toxicity in preterm brain injury. Reprod Toxicol. 2014;48:106-12.

107. Cardoso FL, Herz J, Fernandes A, Rocha J, Sepodes B, Brito MA, McGavern DB, Brites D. Systemic inflammation in early neonatal mice induces transient and lasting neurodegenerative effects. J Neuroinflammation. 2015;12:82.
108. Imai Y, Kohsaka S. Intracellular signaling in M-CSF-induced microglia activation: role of Iba1. Glia. 2002;40:164-74.

109. Lin L, Desai R, Wang $X$, Lo EH, Xing C. Characteristics of primary rat microglia isolated from mixed cultures using two different methods. J Neuroinflammation. 2017;14:101.

110. Shrivastava P, Cabrera MA, Chastain LG, Boyadjieva NI, Jabbar S, Franklin T, Sarkar DK. Mu-opioid receptor and delta-opioid receptor differentially regulate microglial inflammatory response to control proopiomelanocortin neuronal apoptosis in the hypothalamus: effects of neonatal alcohol. J Neuroinflammation. 2017;14:83.

111. Vuong B, Odero G, Rozbacher S, Stevenson M, Kereliuk SM, Pereira TJ, Dolinsky WW, Kauppinen TM. Exposure to gestational diabetes mellitus induces neuroinflammation, derangement of hippocampal neurons, and cognitive changes in rat offspring. J Neuroinflammation. 2017;14:80.

112. Sun J, Pan X, Christiansen LI, Yuan XL, Skovgaard K, Chatterton DEW, Kaalund SS, Gao F, Sangild PT, Pankratova S. Necrotizing enterocolitis is associated with acute brain responses in preterm pigs. J Neuroinflammation. 2018;15:180.

113. Mao XF, Wu HY, Tang XQ, Ali U, Liu H, Wang YX. Activation of GPR40 produces mechanical antiallodynia via the spinal glial interleukin-10/betaendorphin pathway. J Neuroinflammation. 2019;16:84.

114. Sierra A, Paolicelli RC, Kettenmann H. Cien Anos de microglia: milestones in a century of microglial research. Trends Neurosci. 2019;42:778-92.

115. Sierra A, de Castro F, Del Rio-Hortega J, Rafael Iglesias-Rozas J, Garrosa M, Kettenmann $\mathrm{H}$. The "Big-Bang" for modern glial biology: translation and comments on Pio del Rio-Hortega 1919 series of papers on microglia. Glia. 2016;64:1801-40.

116. Rıo-Hortega P: El "tercer elemento de los centros nerviosos". II. Intervenci on de la microglia en los procesos patologicos (celulas en bastoncito y cuerpos granuloadiposos. Bol Soc Esp Biol 1919, VIII:91-103.

117. Karlstetter M, Lippe E, Walczak Y, Moehle C, Aslanidis A, Mirza M, Langmann T. Curcumin is a potent modulator of microglial gene expression and migration. J Neuroinflammation. 2011:8:125.

118. Lin S, Liang Y, Zhang J, Bian C, Zhou H, Guo Q, Xiong Y, Li S, Su B. Microglial TIR-domain-containing adapter-inducing interferon-beta (TRIF) deficiency promotes retinal ganglion cell survival and axon regeneration via nuclear factor-kappaB. J Neuroinflammation. 2012:9·39.

119. Yuan Y, Rangarajan P, Kan EM, Wu Y, Wu C, Ling EA. Scutellarin regulates the Notch pathway and affects the migration and morphological transformation of activated microglia in experimentally induced cerebral ischemia in rats and in activated BV-2 microglia. J Neuroinflammation. 2015;12:11.

120. Jeon $H$, Kim JH, Kim JH, Lee WH, Lee MS, Suk K. Plasminogen activator inhibitor type 1 regulates microglial motility and phagocytic activity. J Neuroinflammation. 2012;9:149.

121. Horiuchi M, Wakayama K, Itoh A, Kawai K, Pleasure D, Ozato K, Itoh T. Interferon regulatory factor 8 /interferon consensus sequence binding protein is a critical transcription factor for the physiological phenotype of microglia. J Neuroinflammation. 2012:9:227.

122. Schmidt C, Schneble N, Muller JP, Bauer R, Perino A, Marone R, Rybalkin SD, Wymann MP, Hirsch E, Wetzker R. Phosphoinositide 3-kinase gamma mediates microglial phagocytosis via lipid kinase-independent control of cAMP. Neuroscience. 2013;233:44-53.

123. Jin R, Yu S, Song Z, Quillin JW, Deasis DP, Penninger JM, Nanda A, Granger DN, Li G. Phosphoinositide 3-kinase-gamma expression is upregulated in brain microglia and contributes to ischemia-induced microglial activation in acute experimental stroke. Biochem Biophys Res Commun. 2010;399:458-64

124. Shang S, Liu L, Wu X, Fan F, Hu E, Wang L, Ding Y, Zhang Y, Lu X. Inhibition of PI3Kgamma by AS605240 protects tMCAO mice by attenuating proinflammatory signaling and cytokine release in reactive astrocytes. Neuroscience. 2019;415:107-20.

125. Smart N, Pries AR, Dirnagl U. Dr Smart talks to Prof Pries and Prof Dirnagl on animal experimentation in biomedical research. Cardiovasc Res. 2017;113:e12-5.

\section{Publisher's Note}

Springer Nature remains neutral with regard to jurisdictional claims in published maps and institutional affiliations. 